The Delta Residence of the Ramessides

Author(s): Alan H. Gardiner

Source: The Journal of Egyptian Archaeology, Vol. 5, No. 4 (Oct., 1918), pp. 242-271

Published by: Egypt Exploration Society

Stable URL: http://www.jstor.org/stable/3853579

Accessed: 26-05-2016 10:11 UTC

Your use of the JSTOR archive indicates your acceptance of the Terms \& Conditions of Use, available at

http://about.jstor.org/terms

JSTOR is a not-for-profit service that helps scholars, researchers, and students discover, use, and build upon a wide range of content in a trusted digital archive. We use information technology and tools to increase productivity and facilitate new forms of scholarship. For more information about JSTOR, please contact support@jstor.org.

Egypt Exploration Society is collaborating with JSTOR to digitize, preserve and extend access to The Journal of Egyptian Archaeology 


\title{
THE DELTA RESIDENCE OF THE RAMESSIDES
}

\author{
By ALAN H. GARDINER, D.LitT.
}

IV

Here at last we come to grips with the problem to which, in a sense, all the foregoing

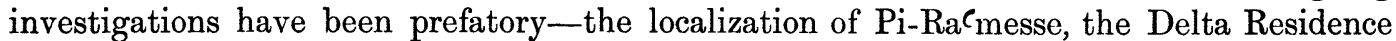
of the Pharaohs of the Nineteenth and early Twentieth Dynasties.

The discussion commenced under no. 39 of the last section provides us with a good point of departure. The researches of recent years have made it practically certain that Thel, the metropolis of the XIVth nome of Khant-yeb, was situated, not at Tanis, but at Tell Abu Șêfeh, an ancient site some $1 \frac{1}{2}$ miles east of ElKanțareh. Mr Griffith, who in 1886 studied the neighbourhood of El-Kanțareh with much care $^{1}$, found there part of an obelisk bearing the names of Ramesses I, Sethos I and Ramesses II, which Prisse d'Avennes had seen and published entire; a few years ago M. Clédat discovered the whereabouts of the missing portion and produced documentary evidence showing that the obelisk came from Tell Abu Șêfeh ("du côté de l'Asie, vers l'est, à environ quatre kilomètres ")2. At Tell Abu Șefeh itself Mr Griffith discovered, obviously in situ or almost so, a base for an image of some sort dedicated by Ramesses II, as well as a Latin inscription from the joint reign of Diocletian and Maximian recording the establishment there of a military station. Both the Ramesside monuments mentioned the god "Horus of Mesen," often referred to as the god of the XIVth nome. This suggested the possibility that the place might be the capital of that nomes, namely Thel or, as it is often transcribed, Zaru, where was a fortress which Tuthmosis III, Sethos I and Ramesses II all had to pass when setting forth on their Asiatic campaigns4. Again, the Latin inscription made it appear likely that Tell Abu Ṣ̂feh was Selle, a town in the eastern Delta where, according to the Notitia Dignitatum (beginning of the Vth century) a Roman garrison was stationed. Now the Antonine Itinerary mentions a Silē at

1 Petrie, Nebesheh and Defenneh, pp. 96 foll., and Plate LI.

2 Recueil de Travaux, vol. xxxI, pp. 113-120, with full publication of the inscriptions of the obelisk.

${ }^{3}$ So in the great Edfu geographical text, BRUGSCH, Dictionnaire Géographique, p. 1366; in the Edfu mythological text, ibid., 1388; in a Philae text, BRUGsch, Geographische Inschriften, vol. III, Pl. V; in two texts at Dendereh, DüMICHEN, Geographische Inschriften, vol. III, Pl. XXIII ; op. cit., vol. I, Pl. XCIX, 1. 21; and doubtless elsewhere.

${ }^{4}$ Tuthmosis III, see Sethe, Urkunden, iv, 647; Sethos I, see Lepsius, Denkmäler, Part III, Pl. 126 a, and above all Pl. $128 b$; Ramesses II, see above p. 179, under no. 2. 
a distance of 24 Roman miles, equivalent to about $22 \frac{1}{2}$ English miles, from Pelusium on the road via Serapeum to Clysma (Suez), and this estimate is but a little in excess of the actual distance-some 19 English miles-between Fârameh and Tell Abu Șefeh' ${ }^{1}$. The identification, thus obtained, of Tell Abu Șêfeh with Silē or Selle suits the old Egyptian evidence admirably, for the name according to the so-called "syllabic" orthography current in the New Kingdom only two consonants that count, and of these $\underline{t}$ appears as $\sigma$ in Greek ( $\left.c f . \underline{T} b-n t r \sum_{\epsilon} \beta \epsilon \nu \nu v \tau o s\right)$, while the other consonant $r$ may equally well stand for $l$; Thel (or perhaps better Șel) is, accordingly, a perfectly legitimate equivalent for the old hieroglyphic name, and the identity of this with Silē, Selē, Selle is apparent. Mr Griffith was, therefore, fully justified in identifying Tell Abu Șefeh with the Pharaonic fortress of Thel and the Roman garrison-town of Sile; but he was less happy in the distinction he attempted to draw between the fortress of Thel and the town of the same name that was the metropolis of the XIV th nome. The reason assigned by him for this distinction was the fact that the XIVth nome of Lower Egypt seemed to correspond to Ptolemy's Sethroite nome, of which the capital, Herakleopolis Parva, ought probably, in his opinion, to be looked for at Tell Belîm (Tell esh-Sherîg) ${ }^{2}$; the town of Thel would, therefore, be situated at Tell Belîm, on the edge of Lake Menzaleh, while the fortress of Thel was at Tell Abu Șêfeh. This theory overlooks the fact, of which we find further instances in the case of the Tanite and Arabian nomes, that an old metropolis was apt to be superseded by some other town that had come to surpass it in importance. In the case of the XIVth nome we may perhaps distinguish three successive capitals : Mesen, the home of the nome-god Horus; Thel, the frontier-town and military centre; and finally, in Graeco-Roman times, Herakleopolis Parva. For all we know, Herakleopolis Parva and Mesen may have been identical; they have no direct bearing on the problem before us, and we therefore cannot discuss them further; but there can be but little doubt that Thel, both town and fortress, is Tell Abu Sêfeh ${ }^{3}$. About Thel we may gather the following additional information. It was on the very edge of the desert and almost outside Egypt; this is indicated by the determinatives $\sim$ accompanying its name in hieroglyphic writing. It was the boundary between Egypt and Syria (Khal), as appears from the epithet "Royal envoy [to the...] countries of Khal from Thel to Yupe." Again, in Haremhab's time criminals were sent thither, docked of their noses, just as in later times they were sent to 'Pıрокороира, a place that owed its name to that barbarous form of punishment 5 . On the other hand, Thel lay on the border of the cultivation, for it pos-

1 For the evidence as to Silē see Küthmann, Die Ostgrenze Aegyptens, pp. 5, 38-40. The distance from Clysma to Serapeum, according to the Antonine Itinerary, was 50 miles; the remainder of the road to Pelusium is given as follows :

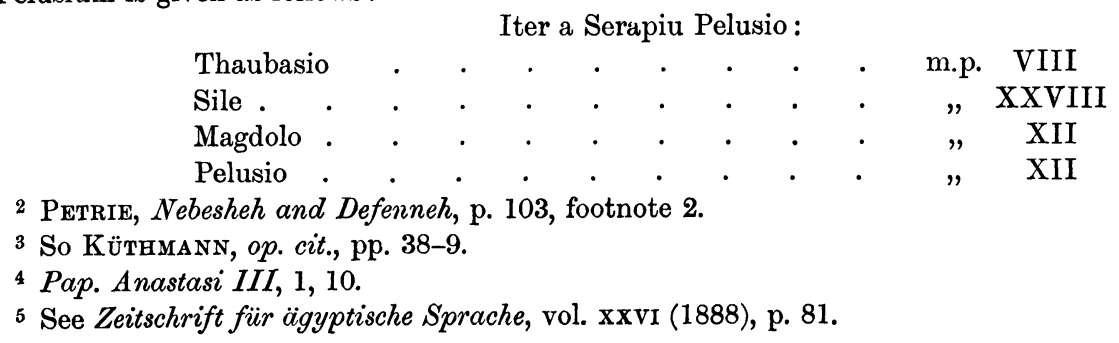


sessed vineyards whence wine was sent to the Theban Ramesseum ${ }^{1}$; and it was accessible by water ${ }^{2}$, probably by a canal which later, at least if local tradition, backed by some slight classical authority, can be trusted, extended to Ostracine, now El-Flûsîyeh at the east end of Lake Sirbonis ${ }^{3}$. We must not forget to mention here the interesting sculptured scene on the north wall of Karnak, where the fortress of Thel is depicted as it was in the time of Sethos I4. In conclusion, reference must be made to some late sarcophagi recently found at Tell Abu Șêfeh ${ }^{5}$; not only do their inscriptions mention Thel, but they also contain ample testimony as to the priestly and divine names connected with the XIVth nome ${ }^{6}$.

It is desirable for our purpose to form some idea as to the extent and boundaries of that nome. Its south-western end, Mr Griffith reasonably supposes, may have lain between Tell Defenneh (Daphnae) and El-Menâgi, since at the latter place a block of Nektanebos was found on which some words are addressed to Buto of Nebêsheh, the capital of the XIXth nome of $\Omega$ 'Imt-pehu "the lower 'Imt-nome," some six miles from El-Menâgi". The natural boundary between the XIVth and XIXth nomes would be the Pelusiac or Bubastite branch of the Nile, which, according to $\mathrm{Mr}$ Griffith, "running W. of Herakleopolis, seems to have turned to the N. a little before reaching Defenneh." Ptolemy makes the Nile the dividing-line between the nomes; between the Busiric and Bubastite river, he says, were (from north to south) the nome of Nesyt with its metropolis Panephysis, the Tanite nome with its metropolis Tanis, and

1 Spiegelbera, Hieratic Ostraca, nos. 163, 189, 203, 211.

2 See above, p. 132, under the letter $\mathrm{H}$.

3 Annales du Service, vol. xvi, p. 8.

4 Lepsios, Denkmäler, Part III, Pl. 128, $b$.

5 Annales du Service, vol. xII, pp. 69-76; Bulletin de l'Institut Frangais, vol. xI, pp. 29-38. Still more recent excavations (Recueil de Travaux, vol. xxxvin, pp. 21-32) produced no inscriptions.

6 The following bibliographical notes may be useful. Brugsch at first (Geographische Inschriften, vol. I, pp. 262-3) identified Thel with Heroonpolis and placed it at the mouth of the Wâdy Tamilat; later, as we have seen, he changed his view and located it at Tanis (see especially Dictionnaire Géographique, pp. 992-7, 1356), J. de Rougé following suit (Géographie de la Basse-Égypte, p. 95). Dümichen, however, laid great stress on a passage in the Edfu texts relating to the myth of Horus, and hence sought to show that Thel lay near Ismailiyeh (Geschichte Aegyptens, pp. 257-60); though he himself subsequently modified his view, placing the town somewhat further north (Zur Geographie des altens Aegyptens, p. 33); this opinion was retained by German scholars until quite recently (e.g. STwindorfF, Die ägyptischen Gaue, p. 6, footnote 2, in Abhandl. d. phil.-hist. Klasse d. kön. Sachs. Ges. d. Wiss., vol. xxvir, 1909), when it was disposed of by Küthmann (op. cit., p. 49). MAx Müller, Proceedings of the Society of Biblical Archaeology, vol. x, pp. 467-77, ignores Griffith, but correctly remarks that Thel would be best located "where the great road from the East crosses the narrowest part of the water between the Birket Ballâh and the

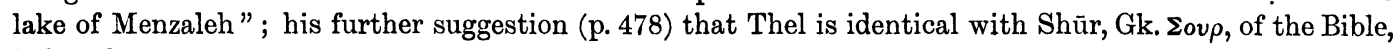
is less fortunate.

To complete the documentation of Thel a few references that do not occur elsewhere in this article may here be added: "split in-fishes of Thel," Pap. Anastasi IV, 15, 7; the fortress of Thel is named in the well-known journal of a frontier-official, Pap. Anastasi $I I I$, verso 3, 5; at Serâbit el-Khâdim was found the stele of a mayor of Thel from the reign of Tuthmosis IV, see Gardiner-PEET, Inscriptions of Sinai, vol. I, Pl. XIX, no. 59, and a stele apparently of the same man is now in Leyden (V 43, see Boeser, Denkmäler des Neuen Reichs, Part III, Pl. XIII, no. 22). There also occurs the personal name T3ry, doubtless meaning "a man of Thel," see Spiegelberg, Correspondances des Temps des Rois-Prêtres, Index, s.v.

7 Petrie, Nebesheh and Defenneh, Pl. XLIII, and pp. 46, 107. 


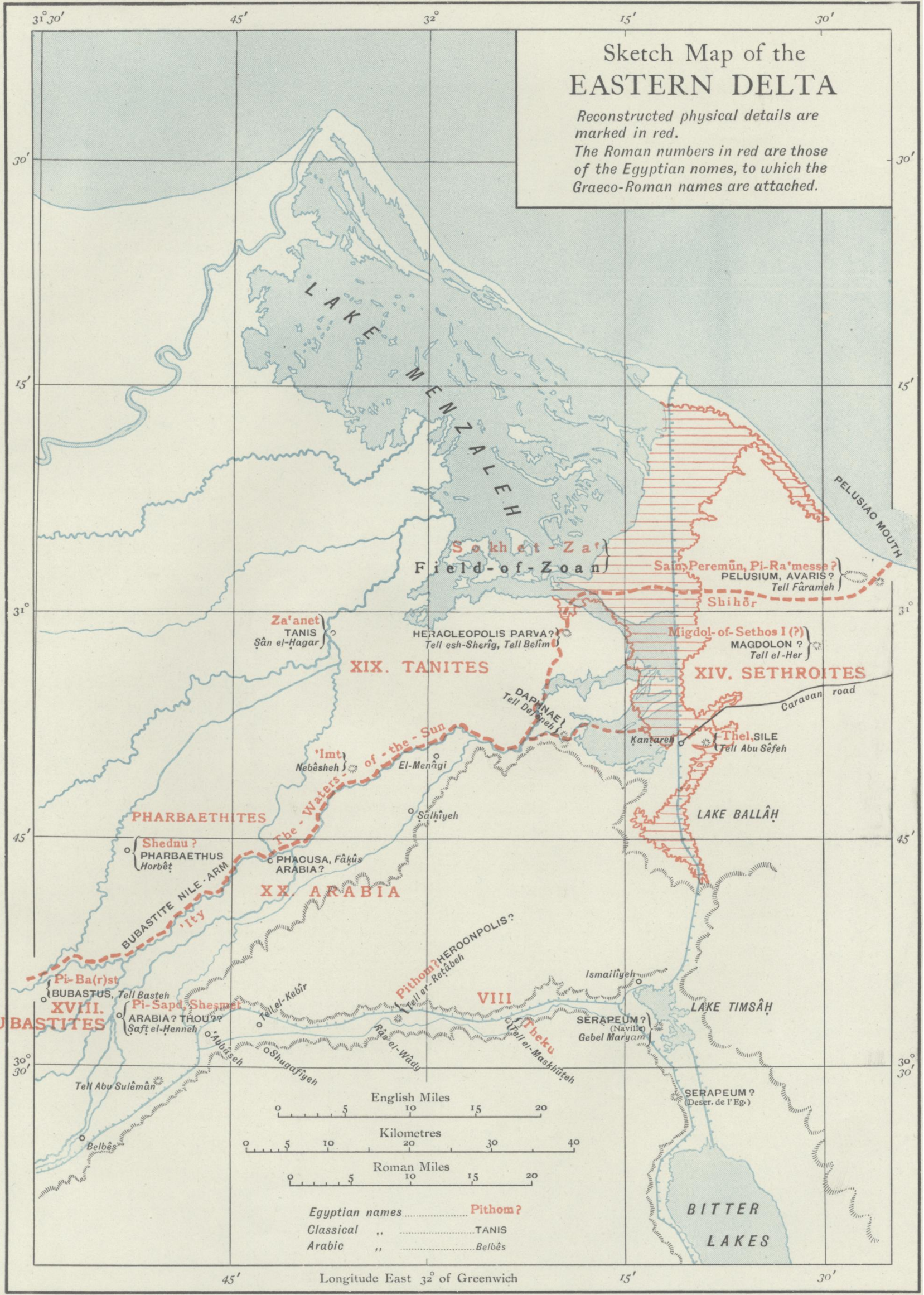


the Pharbaethite nome with its metropolis Pharbaethos ${ }^{1}$; to the east of the Bubastite river were the Sethroite nome with its metropolis Herakleopolis Parva, the nome of Arabia with its metropolis Phacusa, the Bubastite nome with its metropolis Bubastus ${ }^{2}$, and the Heliopolitan nome with its metropolis Oniou. Doubtless this account is too schematic even for Graeco-Roman times, and there is the additional difficulty that the old Egyptian nomes cannot be legitimately equated in all details with those recorded by the classical writers. Still, if it is roughly permissible to identify the XIVth nome with the Sethroites of Ptolemy, then surely we must go further and identify the XIXth nome with Ptolemy's Tanites. As the pivot on which the former identification revolved was the localization of Thel at Tell Abu Șefeh, so that on which the latter identification turns is the localization of 'Imt at Nebêsheh. This was sufficiently proved by Professor Petrie's excavations in 1886, and the same scholar was amply justified in explaining ${ }^{3}$ the Greek name of the nome as due to the fact that Tanis was a city of more recent origin which in course of time had come to overshadow the old religious centre of 'Imt. So too, probably, Phakūsa (Fâkûus) later took the place of Pi-Sapt (Șaft el-Henneh) as the capital of the XXth nome of Arabia ${ }^{4}$, and we have seen that the Sethroite nome may have possessed three successive capitals.

It thus appears that Brugsch, in identifying the XIVth nome with the Tanites and the XIXth with the Sethroites, exactly reversed the truth. Some modern writers on the subject, like Professor Naville, seem clear on the point that the XIVth is the Sethroite nome, but an Egyptologist as well acquainted with Delta geography as M. Daressy still maintains that though Tell Abu Șêfeh was the earlier capital of the nome, later it was eclipsed in importance by Tanis, which then took its place as the metropolis ${ }^{6}$. How improbable a view this is may be seen from a mere inspection of the map; Tanis is some ten miles to the north-west of Nebêsheh, the capital of the XIXth nome, while Tell Abu Șêfeh is about thirty miles due east of the latter place. If there is no very definite

1 The name of the Pharbaethite nome survives in the modern place-name Horbêt, which possibly marks the site of the capital $\check{S} d n w$, the cult-place of Har-merti; see DE RodGÉ, Géographie de la BasseÉgypte, pp. 66 foll., and Annales du Service, Index to vols. I-x, p. 29, s.v. Horbéít. The nome was a late creation, which took in some lists the place of the old nome of $\stackrel{H}{s} b(\mathrm{XI})$, though this was probably situated in a quite different part of the Delta.

2 Bubastus is the form of the place-name preferred by almost all the classical geographers except Herodotus, in contradistinction to the goddess Bubastis. The prototypes of the Tanite and Bubastite nome together originally formed the large nome of 'Imt, part of which was to the right and part to the left of the Bubastite Nile-arm. At an early date the nome of 'Imt seems to have been divided into two, known respectively as the Upper and Lower 'Imt-nomes ('Imt-khant, 'Imt-pehu). In Graeco-Roman times the Pharbaethite nome may have been cut partly out of the early Bubastite nome ('Imt-khant); see last note.

Petrie, Nebesheh and Defenneh, p. 6.

${ }^{4}$ Prof. Naville (Goshen, pp. 14 foll.) contends that Phacūsa must be the modern Șaft el-Ḥenneh, since Strabo (p. 805) states that the canal running from the Nile to the Red Sea branches off from the river at Phacūsa ; this, says Prof. Naville, would be a physical impossibility if Phacūsa were the modern Fakâs. It seems to me easier to suppose that Strabo has confused the earlier and later capitals of the nome than that Fakâs should not be the modern equivalent of Phacūsa. The capital of the nome seems to have been called Arabia in late classical times; see Kürнmann, op. cit., pp. 9-10.

5 Proceedings of the Society of Biblical Archaeology, vol. xxxIv (1912), p. 310. The proposal there made to identify Thel with the Zoar of Genesis xix, 20 is phonetically quite impossible.

${ }^{6}$ Bulletin de l'Institut Français, vol. XI, p. 35. 
evidence beyond its proximity - this indeed would seem enough - to prove that Tanis was in the same nome as Nebêsheh, there is no really valid argument to show that it belonged to the same nome as Thel. Since Brugsch's error still appears to exercise considerable influence, and since a decision on this point has an important bearing upon the problem of the position of $\mathrm{Pi}-\mathrm{Ra}^{\circ}$ messe, his arguments for identifying the XIVth nome with the Tanites must receive very careful examination.

Let us remember that Brugsch, when compiling the Dictionnaire Géographique, had as yet no means of locating 'Imt, the capital of the XIXth nome; nor does he seem ever to have realized the import of Professor Petrie's researches at Nebêsheh, since in his latest utterance (1891) on these geographical problems he still clings to his conjecture that 'Imt signified "the mud-city" (Coptic oмє, lutum) and hence was to be equated with Pelusium". We must take the Dictionnaire Géographique as the clearest expression of Brugsch's opinions. Handicapped by his ignorance of the true whereabouts of 'Imt, he would naturally attach the greater importance to his apparent evidence for the identity of Thel with Tanis. This evidence appears to consist of the following points: (1) Sht-D ${ }^{C}$ t "Field-of-Za $\ell_{a n e t}$ " which is obviously identical with the "Field-of-Zoan" (i.e. Field of Tanis) of the Bible, occurs on several occasions in place of the more usual Shent-De "Field-of-Zac," which is the pehu or "Hinterland" of the XIVth nome; (2) monuments have been found at Tanis which appear to connect that town with Thel (Sile)), because they bear upon them the name either of the town itself or of its gods.

(1) The first point does indeed seem to be a formidable one, and requires the most careful consideration. The name nield-of-Zae" occurs first of all amid a series of representations of inundated districts and the like depicted upon a ruined wall of the temple at Memphis which Ramesses II dedicated to Ptah ${ }^{2}$. The adjacent names are:

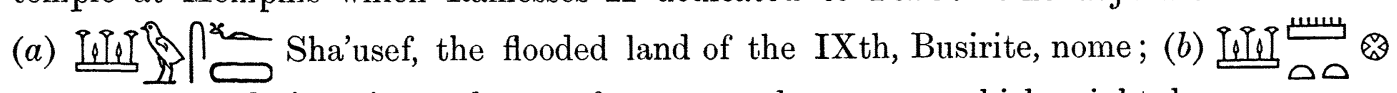
Sha'mentet, a designation unknown from any other source, which might, however, mean

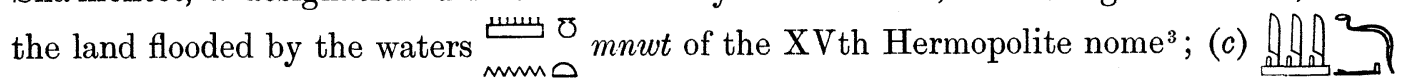
"Field-of-Zac"; (d) GS A Avaris, the well-known stronghold of the Hyksos in the Sethroite nome. The general sequence seems to be from west to east along the northern extremity of the Delta. The addresses to Ptah which accompany these personifications of geographical areas are, as a rule, without interest; alone in the case of "Field-of-Zac" does the accompanying legend contain references that may be of topographical significance. The address in question runs thus: "Ramesses II comes to thee, O Ptah, he brings to thee Field-[of-Zac], "YYIIIIIII,

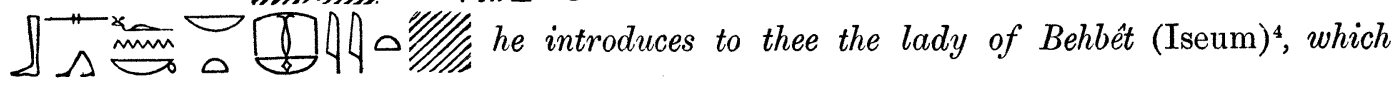

1 Die Aegyptologie, p. 452.

2 Brugsch, Dictionnaire Géographique, p. 270 and p. 1176 ; Mariette, Monuments Divers, Pl. 31; and see too Annales du Service, vol. III, p. 27.

3 BRugsch, op. cit., pp. 1369, 1389.

4 For Hbyt, the modern Behbêt, see particularly RoEDER, Zeitschrift für ägyptische Sprache, vol. xLvI (1909), pp. 62 foll. 
Ramesses II gives to thee........." To these words I shall return later. In Graeco-Roman times "Field-of-Zac" is constantly named as the pehu of the XIVth nome"; thus in the great

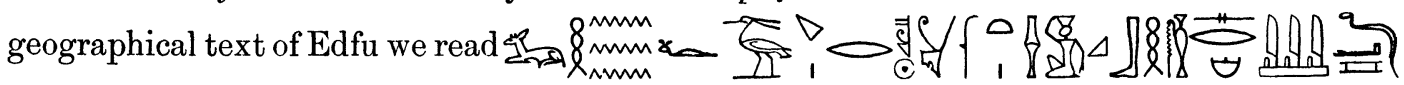
"he (the nome-god Horus of Mesen) inundates the Boinu-land (Phoenix-land) at (its) season of the year, he pours its fresh water into the pehu of Field-of-ZaC." To repeat what was said under no. 39 of the last section (p. 200) the title for 0 ( in the regions of Field-of-Zalanet" occurs on one of the statues of Teos among titles that point unequivocally to the nome of Khant-yeb (XIV) and not to that of 'Imt-pehu (XIX).

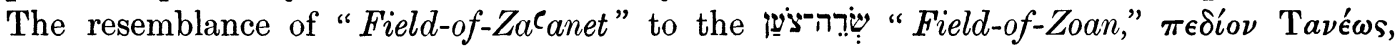

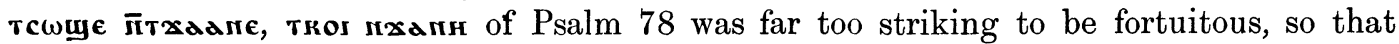
Brugsch could conclude with some show of reason that the nome to which "Field-of-Zac," "Field-of-Zacanet" belonged was the nome of Tanis. That "Field-of-ZaCanet" is no mere mistake on the part of a scribe is shown by the facts that a Ptolemaic stele in Cairo ${ }^{2}$

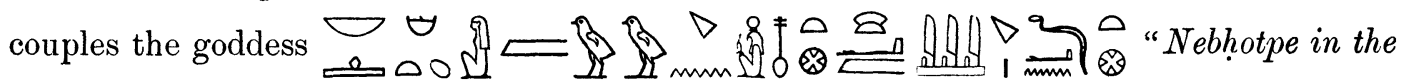
territory of Racnüfer, arising in Field-of-Zacanet" with the god of the fourteenth nome "Horus of Mesen, the noble flying scarabaeus, protecting the two lands, great god of Thel,"

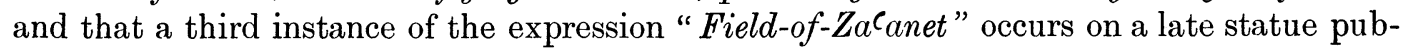
lished by M. Daressy ${ }^{3}$ in a more or less close association with Thel. The text inscribed on the statue is very obscure, but it is somehow narrated of its owner, the general Amenpiom, that his business was to superintend the irrigation of the north-eastern nomes:

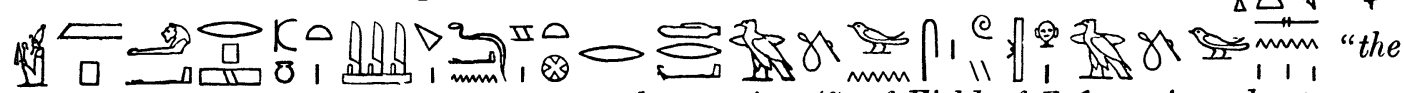
king appointed him as the governor over the province (?) of Field-of-Za $\ell_{a}$ anet in order to prevent the oppression of...... in their oppressions (?)." Then follow some extremely unintelligible sentences, the text of which, according to M. Daressy, runs as follows :

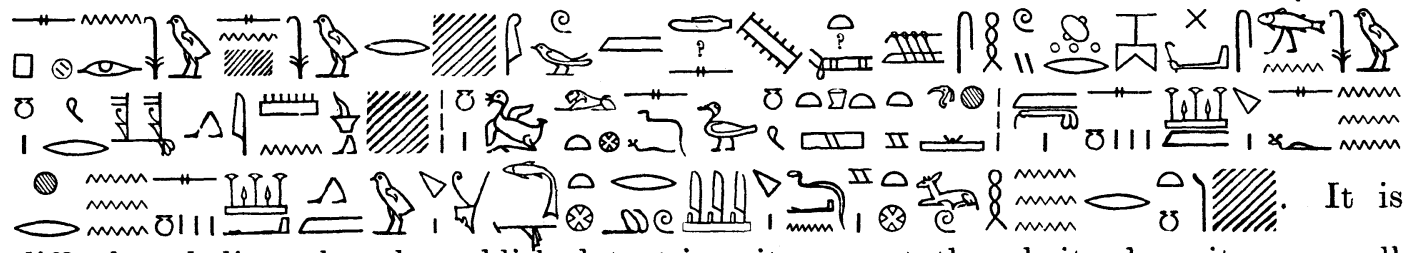
difficult to believe that the published text is quite correct, though its obscurity may well be due in some part to the ancient sculptor. The following rendering will, however, give some notion of its contents: "in order to punish the deed of him who commits it and who transgresses (??) it, in order to free ([s] $]$ šw ?) (it) from ruins (?) which fail to receive mud (i.e. he had to remove brick ruins which prevented the inundation from spreading its mud over the area in question ??) and in order to divide (?)......near the ...... of Thel. He made prolific the good territories in front of them, Sha'sef (there is an intrusive $m$, which makes it

1 BRUGSch, Dictionnaire Géographique, p. 1373. A few other references, Dümichen, Geographische Inschriften, vol. I, Pl. XIV (Edfu); Pl. XXVIII (Dendereh); vol. Iv, Pl. CXX (Dendereh); GriffithPetrie, Two Hieroglyphic Papyri, Pl. X, frag. 18.

2 See Bulletin de l'Institut Frangais, vol. xI, p. 36, for a full bibliography of this monument.

3 Recueil de Travaux, vol. xv, p. 150. 
doubtful whether Sha'usef, the flooded land of the Busirite nome mentioned above, is really meant) being with (?) their waters, and from the territory of the Mendesian nome as far as Field-of-Za canet being inundated every [year]." After making all allowances for mistranslation, it is clear that the general Amenpiom was charged with the duty of looking after the irrigation of the extreme north, from the Phatnitic mouth eastward to "Field-of$Z a$ Canet"; the latter is somehow connected with the name of Thel.

These three instances of "Field-of-Zacanet" appear to me to place its equivalence with "Field-of-Zac" beyond a doubt. "Field-of-Zac" appears, so far as our evidence goes, to be the older form; the later variation can only be explained by taking nine adjective agreeing with sht "field" in place of the old genitive ${ }^{2} \underline{d}^{c}$, "Zac." Egyptian does display analogous adjectival formations, $c f . \infty \square$ mhnt "the Northern House" and the like; compare the Semitic terminations, Arabic آنُ-, Hebrew ji-z. If then "Field-of-ZaCanet" is to be accepted, like "Field-of-Zac," as a name of the pehu of the XIVth nome, we must face the fact that the nome whose capital was at Tell Abu Ṣefeh possessed a pehu having its name compounded with the name of Tanis-Zoan. For the identity of "Field-of-Zacanet" with the Biblical "Field-of-Zoan" is beyond dispute, and the LXX and Coptic equivalents prove that the latter contained the name of Tanis; on the other hand $\underline{D}^{\boldsymbol{C}_{n}} \mathrm{t}$ is really the Egyptian name of Tanis, though this fact was until comparatively recently merely a deduction based by Brugsch on the term Annals of Assurbanipal had indeed afforded the Assyrian transcription Sa'anuª

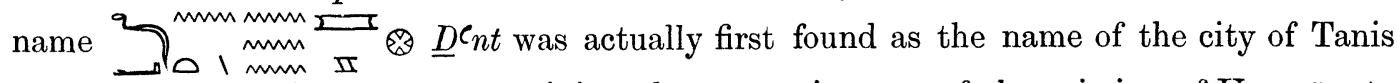
in M. Golénischeff's papyrus containing the romantic story of the mission of Unamun to Phoenicia; here it appears as the seat of government of Smendes, the founder of Manetho's XXIst Tanite government, and as a port where the prince of Dor alone had twenty tradingvessels $(1, x+23)$. The city-name $\underline{D} C_{n t}$-Za ${ }^{C}$ anet has since been encountered in the Golénischeff glossary (above no. 38), on the Stele of the Adoption of Nitokris, and in the Demotic tale of Petubastis.

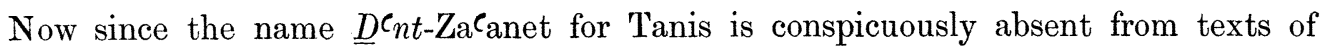
earlier date-at Tanis itself it does not occur at all except in "Field-of-Zalanet" on the statue of Teos-it seems likely that it owes its origin to the proximity of the "Field-of$Z a$ C," which may well be a rather wide expression signifying the region of Lake Menzaleh. How great was the extension of the "Field-of- $Z a c$ " we do not know; if any importance is to be attached to the words on the Memphite wall addressed to Ptah in connection with it, then we should have to conclude that it covered the whole marshy region lying between the region north of Tell Abu Șêfeh and the Phatnitic mouth; the statue of Amenpiom, however, indicates a less extension. In any case, it is necessary to emphasize the fact that because the pehu of a nome has a name that can be associated with a place which

1 See Erman, Ägyptische Grammatik3 $\$ 236$.

2 See H. Ranke, Keilschriftliches Material zur altägyptischen Vocalisation, p. 34, in Abh. d.kổn. Preuss. Akad. d. Wiss., 1910, where, however, Șa'anu is not properly distinguished from Și'inu, guessed by Prof. Spiegelberg to be Pelusium; see below p. 253. 


\section{THE DELTA RESIDENCE OF THE RAMESSIDES}

would otherwise be considered to lie outside that nome, this is no reason whatsoever for including the said place in the nome to which the pehu in question belongs ${ }^{1}$. We know hardly anything as to the real nature of the pehu; the word seems to mean "Hinterland" or "back-lying district"; in the great Edfu geographical inscription it would appear to signify the region into which the river of the nome pours its waters (see above, p. 247, top). Even this is doubtful, however, for the pehu of the Arabian nome (XX) bears the same name 乙II Fomm 'Ity as the "river" of the Heliopolitan nome (XIII) farther upstream", though this seeming contradiction may be reconciled by supposing that 'Ity was one name of the entire stretch of the Bubastite river from the Heliopolitan nome to below that of Arabia. What is more illuminating for our present argument, the pehu of the IVth nome, that of

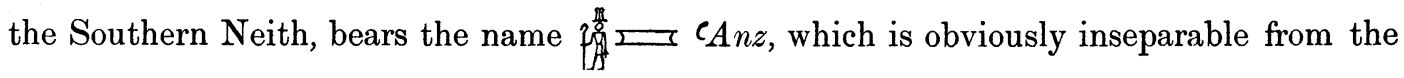
name and the deity of the IXth, the Busirite, nome 湑 $^{3}$ that lay wholly or partially to the north of the IVth nome.

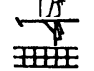

(2) It cannot, therefore, be proved from the term "Field-of-Zalanet" that ZalanetTanis lay within the XIVth nome, and so far as the testimony of this expression is concerned we may still regard the Bubastite river as the dividing line between the Sethroites (XIV) and the Tanites (XIX). It remains, however, to examine the second argument that seems to have influenced Brugsch, namely the fact that Thel, or the god of Thel, is named on certain monuments discovered at Tanis, whence it might seem natural to identify Tanis and Thel. Little weight can be attached to the application of the title "Commander of the Fortress of Thel" to the Vizier Pra Cmesse who accompanies Ramesses II on the Stele of Four Hundred Years, where Ramesses II is depicted offering to Sêtekh-of-Ramesses ${ }^{4}$. It must be admitted, on the other hand, that the statues of Teos come from Tanis, and that one or two Ptolemaic stelae found in the excavations there either mention Thel or are dedicated to the Horus of Mesen 5 . Other Ptolemaic stelae from Tanis, however, are dedicated to Buto of Nebêsheh ${ }^{6}$, though her name scarcely occurs upon the earlier monuments from that site. M. Daressy tells us that the chief deity of Tanis was Amen-Rế, and he accordingly quotes a late stele from Memphis where the divinities of Thel are associated with Amen-Rếc as proof that Tanis later replaced Thel as capital of the XIVth nome? ${ }^{7}$ As a matter of fact Amen-Rếc hardly occurs on the Tanite monuments, though the rulers of the XXIst Dynasty, spoken of as "the officers whom Amen-Rēc has given to the north of his land"," may well have shown to the god of

1 In my discussion of the town of Avaris (Journal of Egyptian Archaeology, vol. III, pp. 99-101) I failed to realize this point, and the remarks there made on the relationship between the XIVth and XIXth nomes consequently require revision.

2 Brugsch, Dictionnaire Géographique, pp. 1369, 1373.

3 See Griffith, Proceedings of the Society of Biblical Archaeology, vol. xxI, pp. 278-9, for the reading for these names.

4 The most accessible reproduction is BuDge, History of Egypt, vol. III, p. 157.

5 Petrie, Tanis II, Pl. X, nos. 168, 170.

Op. cit., Pl. X, nos. 164, 165 . She occurs also on a statue usurped by Meneptah, Tanis I, Pl. I, no. 3 , в.

This stele has been already quoted in another connection, see above p. 247, with footnote 2.

8 Unamün, II, 35.

Journ. of Egypt. Arch. v. 
their Theban home more consideration than previous Pharaohs had done. To tell the truth, the documents at our disposal do not permit us to decide what special cults were most in favour at Tanis; Mr Griffith, who made a careful investigation of this question, summed up his opinion as follows": "The search for a local mythology and really local worship has not been successful. When we have sifted out the national gods who change with the dynasties (the Ptah, Osiris, and Sokar of the Middle Kingdom; Set of the Hyksos; Set, Harmachis, Tum, Tathnen and Amen of the Ramessides) there is no residuum left sufficient to certify a local worship. Set, Uati a p taui and Horus of the foreigners, wear a semblance of localization."

The uncertainty of which Mr Griffith here complains would be much increased if a plausible theory recently put forward by M. Daressy were to prove true ${ }^{2}$. Combating the late Sir Gaston Maspero's hypothesis of a special Tanite school of Art, he argues that the Ramesside and later Pharaohs who adorned the great temple of Tanis transported thither, and particularly from Memphis, many of the older monuments found on the site; only thus, he considers, can we explain the prominence of the Memphite Ptah on a number of the early statues excavated at Tanis. M. Daressy does not extend his theory to the monuments naming Seth of Avaris, since though he does not admit the identity of Avaris and Tanis, he thinks that those towns were quite close to one another. Manetho, however, distinctly says that Avaris lay to the east of the Bubastite river and in the Sethroite nome; I have tried elsewhere ${ }^{3}$ to make it probable that Avaris was Pelusium or at all events near it, a view for which, as we shall see, there is evidence in tradition. Still, just as Thel was close enough to Tanis for its gods occasionally to be mentioned there, so may Avaris also have been. Whether or no, therefore, we suppose that the monuments discovered at Tanis and bearing the name of Seth of Avaris were moved thither by the kings of the Nineteenth or of the Tanite Dynasty, no serious evidence is forthcoming for the view that Seth was the principal god of Tanis. The same argument applies to the monuments naming the Seth of Meneptah, who, as will be shown subsequently, was merely the Seth of Pi-Ra ${ }^{\prime}$ messe under another name. From the coins of the Tanite nome it appears that its predominant cult was that of the falcon-god Horus.

To sum up the results of the last few pages, there is no evidence favouring the view that Tanis was in the nome of Khant-yeb which can outweigh the inherent improbability of such a supposition. The actual topographical conditions demand imperatively that Tanis should belong to the nome of which Nebêsheh was, at one time at least, the capital ; we are, therefore, justified in identifying the Tanites with the nome of 'Imt-Pehu (XIX) and in assuming, until contradictory facts make their appearance, that in the Pharaonic times, as also later, the Bubastite branch formed the boundary between the XIVth and the XIXth nomes.

This elaborate discussion of the relationship between the two north-eastern nomes of the Delta may have seemed irrelevant to the particular question here at issue; in reality it has cut away the ground beneath Brugsch's identification of Pi-Racmesse with Tanis. That identification rested to no small extent on the occurrence of the title "priest of Amün of Ra Cmes of Pi-Ra Cmesse" on the statue of Teos found at Tanis (above p. 199, no. 39), where it was associated with various priesthoods connected with Thel and with

\footnotetext{
1 Tanis I1, p. 34.

2 Annales du Service, vol. xvir, pp. 164-176.

3 Journal of Egyptian Archaeology, vol. III, pp. 99-101.
} 
the XIVth nome. We now realize that Thel was Tell Abu Șefeh and not Tanis, as Brugsch supposed; but still if Tanis had been in the same nome as Thel the title in question might have seemed to point naturally to the equation of Pi-Ralmesse with Tanis, the more so because Tanis possesses an abundance of Ramesside monuments and was also virtually a sea-port, as we have learnt from the narrative of Unamūn. Knowing what we now know about the relations of the XIXth and XIVth, the Tanite and the Sethroite,

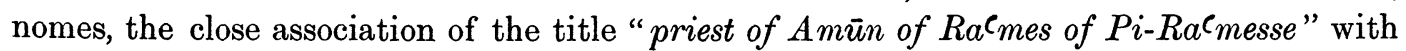
titles belonging to the XIVth nome either indicates nothing at all or else indicates that

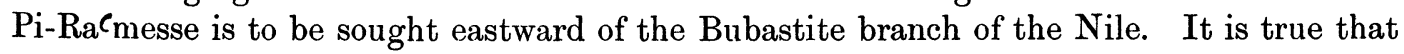
the statue of Teos was found at Tanis, and its owner may therefore have held some offices there. But that would not prove that the Tanitic and Sethroitic nomes were in any way fused or inseparable; the general Nektanebos who lived under Ptolemy Soter was governor not only in Thel (Silē), but also in 'Imt (Nebêsheh) and Thebnūte (Sebennytos)'. Similarly the owner of the Sarcophagus Louvre D 1 (quoted above p. 130, under C) appears to have held priesthoods in various cities in by no means close proximity to one another. Numberless other examples of the same kind could be quoted.

If no convincing argument can be based on the testimony of the statue of Teos adduced by Brugsch, another piece of evidence that he employed can now be made to weigh heavily against him. In the long description contained in Pap. Anastasi III (above p. 184, no. 15) of the delights and riches of Pi-Ra ${ }^{2}$ messe, a number of localities are named which must necessarily lie in the neighbourhood, though possibly not in the immediate neighbourhood, of that city. Unhappily only one of the names is identifiable : in 2, 8-9 it is said that "The-Waters-of-Horus yield salt," and three lines further on we find the sentence, "The reed-swamps come to it (Pi-Ralmesse) with papyrus, and The-Waters-ofHorus with rushes." Now the name "The-Waters-of-Horus," is obviously the same as the SII-Hir "Waters-ofHorus" frequently mentioned by the Graeco-Roman texts in connection with the XIVth nome ${ }^{2}$. In the great geographical inscription of Edfu "Waters-of-Horus" is the "river" ( $4 \circlearrowright \bigodot$ ) of the XIVth nome-the stream or strip of water upon which"floated the sacred bark "Beautiful-is-Mesen"." Most of the references to "Waters-of-Horus" in the late temples are devoid of geographical interest, but once ${ }^{4}$ in a legend that accompanies a figure of the king pouring libations we read, "These thy libations come forth from Elephantine, $\widehat{C}$ C they arrive at Waters-of-Horus, that thou mayst drink of them," etc.; apparently the purpose of the writer was to say that the Nile is offered to the god in its full extent, from Elephantine and the First Cataract down to "Waters-of-

1 Sethe, Urkunden, II, 24-6.

2 E.g., Dendereh, Dümichen, Geographische Inschriften, vol. Iv, Pl. CXX; Marietre, Denderah, vol. I, Pl. 66 a, 7. At Edfu, $c f$. DüMIChen, op. cit., vol. III, Pl. XXIII; DE RougÉ, Edfou, Pl. XXVI; op. cit., Pl. LXIII ; PIEHL, Inscriptions Hiérogtyphiques, vol. II, Pl. CII, F. Only indisputable references to the

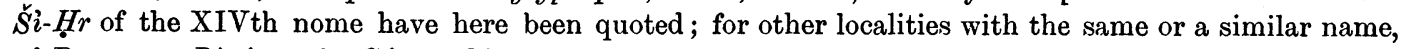
cf. Brugsch, Dictionnaire Géographique, pp. 519, 1261.

3 Brugsch, op. cit., p. 1369.

4 At Edfu, see PiehL, op. cit., Pl. CVIII, L; cf. also Mariette, op. cit., vol. I, Pl. 10. 
Horus," its northernmost reach. From this and various other passages it seems evident that "Waters-of-Horus" must be a stretch of running water; it cannot (e.g.) be equated with Lake Ballâh, nor again is it likely to have anything to do with the canal, already mentioned, which connected Thel with the Nile. For the Egyptian the only drinkingwater that seemed desirable was that of the Nile, and it is therefore necessary to regard "Waters-of-Horus" as name of a part of the Nile itself. From the circumstances of the case it can only be the name of that stretch of the Bubastite branch which we must presume to have formed the western boundary of the XIVth nome, in other words the stretch which debouched at or near Pelusium.

This conclusion is confirmed in a quite remarkable manner by the place-name Shihōr familiar from the Old Testament. The Hebrew name שִיחו Shihōr, once (Joshua xiii, 3) preceded by the definite article הַنְשיחור Hash-Shihōr, is an impeccable equivalent of the Egyptian \& of-Horus." "Two of the passages where Shihor occurs prove it to be a name of the Nile or a part of it, and the other two equally clearly show that it marked the potential or actual boundary between Egypt and the land of Israel. In Isaiah's "Burden of Tyre" (xxiii, 3) we read, "And on great waters the seed of Shihor, the harvest of the Nile, was her revenue"; and the prophet Jeremiah asks (ii, 18), "And now what hast thou to do in the way to Egypt, to drink the waters of Shihor?" Again, when Joshua was grown old, there remained yet much land to be possessed by Israel, "all the regions of the Philistines, and all the Geshurites; from the Shihor which is before Egypt, even unto the border of Ekron northward" (Joshua xiii, 3); and in the history of David, "So David assembled all Israel together, from Shihor of Egypt ${ }^{2}$ even unto the entering in of Hamath" (I Chronicles, xiii, 5). It is strange that these very explicit passages could ever have been misinterpreted ${ }^{3}$; neither the Hebrew Shihor nor the Egyptian "Waters-of-Horus" can well be understood otherwise than as designations of the lower reaches of the Bubastite or Pelusiac Nile-arm.

Thus the association of "Waters-of-Horus" with Pi-Ralmesse indicates the identity of the latter, not as Brugsch supposed with Tanis, but rather with Pelusium or at all events with some town situated near the sea on the Bubastite branch of the Nile. With the Biblical passages representing Shihor as the boundary of Israel one may compare the Egyptian texts describing Pi-RaCmesse as "betwixt Zahi and Egypt" (no. 17) and as "the forefront of every land, the end of Egypt" (no. 16). That Pi-Ra Cmesse was a sea-port, whether actually beside the sea or some little distance inland beside the river-mouth, is shown by the words "the harbourage of thy ships' troops" (no. 16); "its ships fare forth and return to port" (no. 15).

In parting company once and for all with Brugsch and his theory of the identity of Pi-Ra $C_{\text {messe }}$ and Tanis, let us recall the decisive evidence of the Golénischeff Glossary (no. 38), where Pi-Ralmesse is distinct both from Thel and from Tanis.

1 The equation is perhaps due to Brugsch, the first mention of it that is known to me being Die Aegyptologie (1891), p. 451. Dr Küthmann (op. cit., p. 41, footnote 2) has rightly revived it.

2 R.V. gratuitously inserts after Shihor "the brook." This insertion rests on the supposed identity of Shihor with "the brook of Egypt" named (e.g.) Numbers xxxiv, 5, and generally taken to be the Wâdy el-`Arîsh.

3 Brown-Driver-Briggs, Hebrew Lexicon, s.v. Shihōr, takes the correct view, as does also E. Meyer, Die Israeliten und ihre Nachbarstämme, p. 457, footnote 1. Cheyne, Encyclopaedia Biblica (s.v.), deals with the name in a characteristically fanciful way. 
As we have seen, it was Chabas who first voiced the possibility that Pi-Ralmesse was Pelusium or in its neighbourhood; apart from Max Muiller, whose adhesion to this theory seems to have been quite transitory, it has found no supporters. Chabas attached much weight to the passage in the "Poem of Pentaur" (no. 2), whence we learn that Ramesses II passed the fortress of Thel before reaching the town of Ramesses; but in view of the defective text, and the consequent uncertainty whether the particular town of Ramesses there meant was the Delta capital, we have pledged ourselves not to use this passage otherwise than as corroborative evidence. What further arguments can be adduced in favour of our thesis? Thus far we have ascertained that Pi-Ralmesse was intimately associated with Shihōr, a name of the lower reaches of the Bubastite Nile-arm; further, that it was near the sea and was distinct from Thel. Certain epithets, moreover, indicate that it lay on the extreme eastern border (p. 252). But it did not lie on the route between Thel and Raphia; else it would have been named in the comprehensive list of names of places on that route contained in Pap. Anastasi I, 27, 3-8. Beyond these details and the fact that Pi-Ralmesse was accessible by water from Heliopolis (no. 8) we have no direct or certain information as to its whereabouts. But there remains a certain amount of indirect and not quite demonstrable testimony which, taken in bulk, renders it exceedingly probable that Pi-Ralmesse stood on the site known to the Greeks as Pelusium, "the city of mud."

Pelusium, as has been said already, was situated at the approximate distance of 24. Roman miles from Sile (Thel) and must have lain in the same nome. The ruins, now known as Tell Fârameh, have been described by $\mathrm{Mr}$ Griffith ${ }^{1}$ and, more recently, by M. Clédat ${ }^{2}$. Thus far the only monuments of Pharaonic date discovered there have been a weight bearing the name of the Pharaoh Nektanebos, part of a sarcophagus of the same period, and a small fragment of a temple scene (or the like) that appears to belong to Ramesside times ${ }^{3}$. There exists evidence, however, that the town was a very old one. Its original name may have been $\int_{\varnothing} \dot{S}(i) n w$, this occurring already in the Pyramid Texts as the provenance of a particularly good kind of wine; the name possibly means "stronghold" $\left(f_{0} \mathrm{sm} \pi\right)$. The native Egyptian inscriptions of the Pharaonic period do not allude to Sinw except in this connection, but the Annals of Assurbanipal name Sharlûdâri, prince of Și'inu, as one of the Delta chieftains subjugated by the Assyrians; Și'inu here must be a city distinct from Șa'anu-Tanis, since the prince of that city bore the name of Petubishti (Petubastis). In Demotic two references to a town of similar name are found: the Vienna novel of Petubastis sends that warrior "into the provinces of Egypt from Elephantine to Swn," where Swn must obviously be a place in the extreme north; in the geographical manual Pap. Cairo 31169, 3, 26 a place Sw we must assume it to be just outside the borders of Egypt. A few years ago Professor Spiegelberg, combining these data with the prophecy Ezechiel xxx, 15, "I will pour my anger upon Sin, the strength of Egypt," where the Vulgate has Pelusium for the Hebrew Qִ (probably to be vocalized $\Sigma a \iota \nu$ with the Septuagint), made out a plausible case for the

1 Petrie, Nebesheh and Defenneh, pp. 99-101.

2 Annales du Service, vol. xIII, pp. 79-85, with a plan of the ruins. The general position of the town is best shown by Clédat's map, op. cit., vol. $x$, unnumbered Plate referring to the article, pp. 209-237.

${ }^{3}$ Recueil de Travaux, vol. xxxvIr, pp. 33-4. 


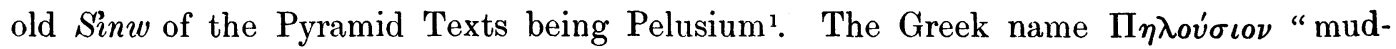
city" would on this view be a popular etymology from the Egyptian word 14 in $\sin$ "clay," "mud." Modern scholars have always adhered to the Vulgate's identification of "ִ in Ezechiel with Pelusium, both because Pelusium suits the requirements of the passage well and because of the Syriac word $s^{c} y \bar{a} n a$ "mud," which seemed to furnish the Semitic equivalent of the Greek name". Professor Erman attempts to reconcile these conflicting etymologies by regarding the Egyptian word sin "mud" as the source both of the Syriac $s^{C} y \bar{\alpha} n a$, which has no good Semitic affinities, and also of the Greek translation $\Pi \eta \lambda$ ov $\sigma \iota \nu \nu$.

Leaving now these rather doubtful philological details, we may take it as possible that Sainu or some similarly vocalized name was the commonest Egyptian designation of the important and historic town of Pelusium ${ }^{3}$. But Egyptian towns have, as has been noted previously, a way of possessing several different names, and it is by no means unlikely that this may have been the case with Pelusium. In the confused and undoubtedly composite story told by Josephus about the expulsion of the Hyksos and the Exodus of the Jews, Pelusium is several times mentioned in a manner that leaves no doubt in the mind that it was thought synonymous with Avaris. The Heliopolitan priest Osarsiph had been made ruler of the lepers set apart by king Amenophis in Avaris (contra Apionem, ed. NABER, I, 238-9); Osarsiph now sends to Jerusalem to the descendants of the Hyksos who had been driven out of Avaris by Tethmosis, and begs them to return thither (op. cit., I, 242-3). This they do, but at a subsequent stage of the narrative it is at Pelusium, and not at Avaris, that the army of the son of Amenophis, according to Manetho, encounters the lepers (op. cit., I, 274). In the still more muddled version of the legend ascribed by Josephus to Chairemon, Moses-Tisithen and Joseph-Peteseph arrive at Pelusium and find 380,000 men left there by Amenophis, he not wishing to take them into Egypt; Moses and Joseph enter into a league of friendship with them and join them in an expedition to Egypt (op. cit., I, 290-1; cf. also 302); Pelusium is here what Avaris is in the other accounts, the place of assembly for foreigners and rebels engaged in warfare against Egypt.

Now as I have shown elsewhere 4 , the scanty data we possess concerning the position of Avaris point to its having been situated in the neighbourhood, if not on the actual site, of Pelusium, so that the tradition as to the identity of the two places handed down by Josephus is entitled to a respect which would not have been due to it had it stood alone. There are, however, certain indications which make it by no means improbable that $\mathrm{Pi}-\mathrm{Ra}^{\mathrm{C}}$ messe stood on the site of the old Avaris, and consequently is none other than Pelusium itself; possibly even the story told by Josephus may contain a hint of this, for that story describes how numbers of Egyptians and foreigners were gathered together into Avaris-Pelusium during the Ramesside age, just as it is said in a poem about Pi-Ra $C_{\text {messe }}$

1 Zeitschrift für ägyptische Sprache, vol. xLIX (1911), pp. 81-4. Spiegelberg makes out a fairly good case for transcribing the old Egyptian name as Śinw, though in a number of instances Śsw, with $w$, is written.

2 Max MüLler, Encyclopaedia Biblica, art. Sin (written before the appearance of Spiegelberg's essay), rejects the identification of the Sin of Ezechiel with Pelusium.

${ }^{3}$ For the bistory of Pelusium in classical and medieval times, see a good popular account by Dr W. F. Hume in the Cairo Scientific Journal, vol. Ix (1917), pp. 54-63.

4 Journal of Egyptian Archaeology, vol. III, pp. 99-101. 
translated above (no. 17): "Everyone hath left his town and settled within its territory." Apart from this, however, the prominence of Sētekh in both Avaris and Pi-Ralmesse is a point strongly in favour of the identity of the two places. The gods of Pi-Ralmesse, as we learn from the evidence set forth in the last section, were as follows:

"Amün-of-Ramesses-Beloved-of-Amün" (R. II), nos. 1, 4, 17, 20, 30, 31. Of Pi-Racmesse it is said: "Its western part is the house of Amün," no. 17. His temple, no. 1. "Amün-of-Ramesses-Princeof-Heliopolis" (R. III); his temple described, no. 26; it possessed 7872 serfs, no. 27. In late times, "Amūn-of-Ra`mes" (sic), no. 39.

"Ptah-of-Ramesses-Beloved-of-Amün" (R. II), nos. 1, 4, 19, 20, 30, 31. His temple, no. 1. "Ptah-ofRamesses-Prince-of-Heliopolis" (R. III); his temple is described in no. 28, and was apparently attended by $23(16+7)$ persons, but it is not quite certain that this temple was in Pi-Ra'messe.

"Sētekh-great-of-valour-of-Ramesses-Beloved-of-Amün" (R. II), nos. 12, 30; "Sètekh-great-of-valourson-of-Nut" named immediately after Amün and Ptah of R. II, no. 4. Of Pi-Rarmesse it is said: "Its southern part is the house of Sêtekh," no. 17. In the reign of R. III, Pi-Ra'messe had a temple of "Sêtekh-of-Ramesses-Beloved-of-Amūn" (R. II) called "House-of-Ramesses-Prince-of-Heliopolis (R. III)-in-the-House-of-Sêtekh;" this possessed 106 serfs, no. 29.

"Préc-of-Ramesses-Beloved-of-Amün," only nos. 30 and 31.

In addition to these deities, it is once said of $\mathrm{Pi}-\mathrm{Ra}^{\prime}$ messe that "Astarte is in its Orient, and Buto in its northern part," no. 17. On the stele of the Hittite treaty (no. 4), R. II is described as doing the behests of certain gods in the Residence-city; Amen-Rêe, Harakhte and Atum are here named before Amūn of R. II, Ptah of R. II and Sètekh, great of valour, son of Nut, but there is no reason for thinking that the first three gods were specially worshipped in Pi-Racmesse.

It is extremely interesting to find that on several monuments usurped by Meneptah he describes himself alternately as (a) "loved of Sèth, lord of Avaris," $(\beta)$ "loved of Sèth, great of valour," and $(\gamma)$ "beloved of Sêth-of-Meneptah." The monuments in question are : base of statue, Petrie, Tanis I, Pl. II, no. 5 A ( $a, \beta, \gamma$ together $)^{*}$; colossus originally of Sesostris I, now in Berlin, Aeg. Inschr. aus den kön. Mus., vol. II, pp. 19-22 ( $a, \gamma$ together); statue originally of Amenemmes III, now in Berlin, op. cit., vol. II, p. 18 ( $\beta$ only); statue originally of Sesostris I, now in Cairo, Annales $d u$ Service, vol. xvII, p. 170, no. 4 ( $\beta$ only)*; statue originally of Sesostris I, now in Cairo, loc. cit., nos. 5 and 8 ( $\beta$ and $\gamma$ together)*. Those statues here marked with an asterisk are known to have come from Tanis, and the same may be true of the others, as well as of several related monuments yet to be quoted; but we have seen that not much importance is to be attached to this fact in connection with our topographical problem ${ }^{1}$. Now Seth-of-Meneptah is obviously identical with Seth-ofRamesses-Beloved-of-Amūn, who is depicted on the Stele of Four Hundred Years found at Tanis ${ }^{2}$, and named on a sphinx from the same place now in the Louvre ${ }^{3}$. Thus one of the principal gods of $\mathrm{Pi}-\mathrm{Ra}^{\prime}$ messe-we shall return to the others further on-is also the principal god of Avaris, a fact which seems to point to the identity of Avaris and $\mathrm{Pi}-\mathrm{Ra}^{2}$ messe; but if Avaris is Pelusium, then Pi-Ralmesse will have to be looked for at Pelusium too.

With this fact would agree, further, the prominence of Amūn at Pelusium. In Coptic times the town was called пєрємогn, which must surely correspond to an old $\mathrm{Pr}$-'Imn

1 See above, pp. 249-251.

2 The most handy reproduction of this curious monument is to be found in BUDGE, History of Egypt, vol. III, p. 157. On the Seth of Ramesses II, see Griffith's article in Proceedings of the Society of Biblical Archaeology, vol. xvI, pp. 87-89, where it is pointed out that he is associated with Buto of Nebêsheh not only in the titles of the Stele of Four Hundred Years but also on a monument from Nebêsheh itself.

3 A 21, see Sharpe, Egyptian Inscriptions, vol. II, Pl. 44; also Petrie, Tanis, I, Pl. II, no. 25. 
"House-of-Amūn," whatever the reluctance of Egyptologists to recognize the fact ${ }^{1}$; and it is this name which gave rise, it is believed, to the name Tell Fârameh borne by the mounds now concealing the remains of Pelusium². In Roman times the Pelusiac Amūn was called Zeus Kasios, and the remains of his temple have been recently excavated in the middle of the western mound of Tell Fârameh ${ }^{3}$. It is probably the merest coincidence that Pap. Anastasi III, describing Pi-RaCmesse, tells us that "its western part is the house of Amün."

It cannot be denied that the deities of Pi-Ralmesse were contemporaneously worshipped, or at least commemorated, in various other cities besides Pi-Ralmesse itself. Seth-of-Ramesses has been met with at Tanis, and it must now be added that he occurs in company with Ptah-of-Ramesses also at Bubastus ${ }^{4}$; Ptah-of-Ramesses is named on a palette from Thebes ${ }^{5}$ and at es-Sebû $\boldsymbol{C}_{\mathrm{a}}$ in Nubia ${ }^{6}$, and Ptah-of-Meneptah, evidently the same god, is recorded on a lintel from Memphis? . At Tell-el-Yahûdîyeh Amūn-of-Meneptah and Ptah-of-Meneptah are associated with the erased Seth-of-Meneptah ${ }^{8}$. Lastly, Amūn-ofUsimarē $^{-}$-setpenrēe is depicted at $\mathrm{Abu}$ Simbel $^{9}$. So devoted, indeed, was Ramesses II to his four gods Prēe, Amūn, Ptah and Seth that he not only honoured them in his Residence, but also named the four divisions of his army after them ${ }^{10}$. A temple of Prēe-of-Ramesses situated to the south of Memphis has been discussed above (p. 133, under I), but apart from this we have no evidence of an established cult of the gods of Pi-Ralmesse elsewhere than at that city itself. For it is reasonable to conjecture that the chapel of Amūn-of-Usimarēe-setpenrēe dedicated by a queen who may have been Tewosret ("Tausert") of the Nineteenth Dynasty ${ }^{11}$ was at Pi-RaCmesse itself or quite close to it; this is the more likely, since it was placed in charge of an official known as "The Commander of the Fortress of the Sea." But even if we suppose the gods of Pi-KaCmesse to have possessed temples and priests of their own in other towns beside Pi-Ra ${ }^{2}$ messe, it is highly improbable that such cults survived Ramesside times. In Pi-Racmesse itself they may have lingered on, the priesthoods sustaining themselves on the relics of the vast heritage with which Ramesses II endowed them; indeed we know for a fact from the statue of Teos (no. 39) that Amūn-of-Ramesses was attended in $\mathrm{Pi}-\mathrm{Ra} \mathrm{C}_{\text {messe }}$ by a priest as late as the fourth century B.C.

The foregoing argument enables us to estimate at its true value the mention of two of the gods of Pi-RaCmesse on a shrine of red granite dedicated by the Pharaoh Nekhtharhēebet (Dyn. XXX), the fragments of which were discovered by Professor Naville at Bubastus ${ }^{12}$. The two gods in question occur among the delicately sculptured figures of

1 Amélineau, La Géographie à l'époque Copte, pp. 319-20.

2 A different and impossible origin is proposed by BRUGsch, Dictionnaire Géographique, p. 1089; rightly combated by Maspero in Zeitschrift für ägyptische Sprache, vol. xxI (1883), pp. 63-4.

${ }^{3}$ Annales du Service, vol. xvili, pp. 79-85. For references to the temple in classical writers see Wiedemann, Herodots Zweites Buch, p. 63.

${ }^{4}$ Naville, Bubastis, Pl. XXXVI, F, н.

${ }_{5}^{5}$ Berlin 6764; see Zeitschrift für ägyptische Sprache, vol. xxx (1892), pp. 43-6.

${ }^{6}$ Gauthier, Le Temple de Ouadi es-Sebouâ, p. 151.

7 Petrie, Palace of Apries, Pl. XXI.

8 Petrie, Hyksos and Israelite Cities, Pl. XVI.

9 Champollion, Notices Descriptives, vol. I, p. 73.

10 See Breasted, Battle of Kadesh, p. 11.

11 Gardiner, The Stele of Bilgai, in Zeitschrift für ägyptische Sprache, vol. L (1912), pp. 49-57.

12 Naville, Bubastis, Pl. XLVI, в. 
numerous local deities, and their images are accompanied by the legends :

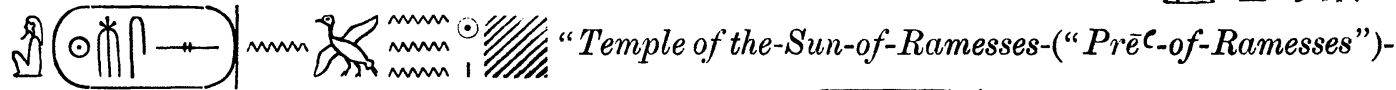
of-The-Waters-of-the-Sun" and 6$]_{0}^{m} 0$ a Ptah-Tanen-of-Ramesses upon the edge of the river." If the argument of the last paragraph is sound, these two legends must teach us, not only that Pi-Ralmesse was situated on a branch of the river, but also that the said branch was named "The-Waters-of-Rēe," "The-Waters-ofthe-Sun." This calls to our mind the three dubious passages recorded in the last section (nos. 35, 36, 37), whence it seemed to emerge that Pi-Ra ${ }^{2}$ messe lay beside a Nile-arm called

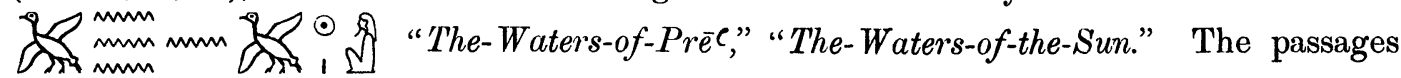
mutually confirm one another and the conclusion to which they appeared to point thus acquires some degree of solidity. What then do we know about "The-Waters-of-the-Sun"?

The earliest occurrence of this name is in a list of nomes, inundated districts and riverarms depicted on the walls of the temple of Sethos I at Abydos: the list concludes with Or. menrēe" (Sethos I), L mmm of "O "The-Waters-of-the-Sun" and another name that is illegible'. On a number of fragmentary wine-jars from the Ramesseum we read of wine from "the great orchard of the Ramesseum (i.e. of Thebes), which is in The-Waters-of-theSun 2." The same branch of the river is mentioned in the Golénischeff Glossary and in the analogous catalogue of place-names, the Demotic Pap. Cairo $31169^{3}$. In Pap. Harris 10, 7-11 is a list of herds of cattle belonging to the estate of Amūn; each herd has a name, and after three of them is an indication of the district where they were pastured ("in the Great-River," "in The-Waters-of-the-Sun," "in the Great-River"). Such at least seems the natural way of interpreting the text; but Professor Breasted attaches the supposed local indications to the names themselves, thus obtaining in the case that concerns us "Herd (called) Usimarēe-Miamūn,-L-P-H,-is-the-conqueror-of-the-Meshwesh-at-the-Waters-ofthe-Sun 4 ." Since, however, the victory of Ramesses III over the Meshwesh here alluded to certainly took place in the west of the Delta ${ }^{5}$, it would necessarily follow that "The-Watersof-the-Sun" was the name of the western branch of the Nile. This agrees with nothing else that we know about this name; moreover, we have seen that the westernmost branch of the Nile was called "The-Western-Waters," "The-Western-River" (above, p. 130, under O).

1 Mariette, Abydos, vol. I, Pl. 14, c; Dümichen, Geographische Inschriften, vol. I, Pl. XCII. “TheWaters-of-Ptah" are named on the fragments of two wine-jars, SpIEgElberg, Hieratic Ostraka, nos. 197, 292. The destroyed name may have been "The-Waters-of-Amün" named on the fragments, op. cit., nos. $153,225,228$. Stress must be laid on the importance of these fragments of wine-jars for a knowledge of the names of Nile-arms and canals in the Delta; they have already been quoted several times in this connection. Note that $\bigsqcup^{L}$ " $\mathrm{Ka}^{\prime}$ " in nos. 186, 209, 217, 218, 221, 243, 269, 289, 292 looks like the original of the "Agathodaemon" river in Ptolemy.

2 Op. cit., nos. 143, 231, 276 ; for no. 264, which may have named Pi-Ralmesse, see no. 37 of last section.

${ }^{3}$ Sphinx, vol. xIv, p. $163 . \quad{ }^{4}$ Ancient Records, vol. Iv, § 224.

5 See above, p. 134, under M.

Journ. of Egypt. Arch. v. 
Professor Breasted is obviously in error, as also a passage now to be quoted tends to show. In the list of dedications made to the less important local deities by Ramesses III are named 169 serfs who were placed $\square_{1}^{5}\left[0_{0}^{\circ} b_{0}\right.$ "in the House of Bast, lady of Brst, in The-Waters-of-the-Sun" (Pap. Harris, 62a, 2). The locality Brst is referred to again in the great Karnak inscription of Meneptah", where (l. 7) it is said that foreign invaders had pitched $\mathbb{H}_{1 / 1}, 4$

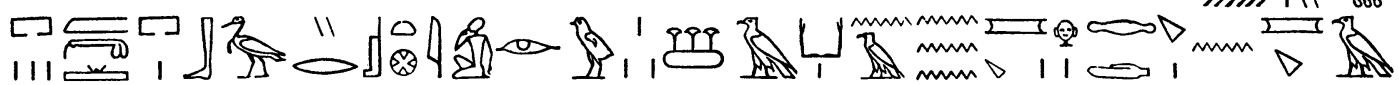
$\min _{\min } \nabla$ "tents in front of Pr-Brst and had made (their) habitation ${ }^{2}$ in the tract of 'Ity.".

Now the name 'Ity is determined with the signs for water, and "the tract of 'Ity" must therefore be the region watered by that described by the great Edfu geographical text as the "river" of the XIIIth (Heliopolitan) and the pehu of the XXth (Arabian) nome"; hence it is plausible to suppose that 'Ity was the name given to the portion of the Bubastite Nile-arm adjacent to those two nomes. Brugsch bears the responsibility for the conjecture that Brst or Pr-Brst is the modern Belbês

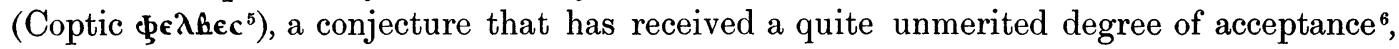
seeing that it rests on nothing more than a superficial consonantal resemblance. There is no evidence that the Bubastite branch ran so far east as Belbês, and it may be guessed that $B r s t$ and $P r$-Brst are but variant names, due to some cause unknown, of $\int_{0}^{0} B 3 s t$ and $\square$ Pr-B3st respectively. At all events it is a fact that in two of the three ${ }^{7}$ instances where Brst, Pr-Brst occurs it is in connection with the goddess of Bubastus. Brugsch and

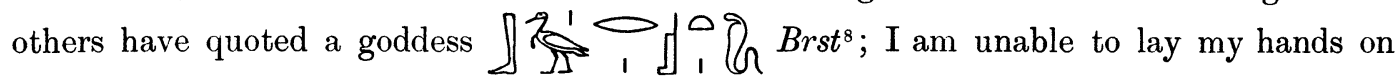
the evidence for her, but if such exists, she is probably only Bast with the name abnormally spelt. This view is confirmed by the occurrence of a writing obviously intermediate between Brst and B3st ${ }^{9}$. The conclusion to be drawn, then,

1 Latest and best edition, MAX MüLLer, Egyptological Researches, vol. I, Pls. 17-32.

$2 \check{S} k n$ is probably a derivative of Hebrew שכ in spite of the determinatives of water; these may be borrowed from 'Ity by a kind of anticipatory attraction; so BURCHARDT, Die altkanaanäischen Fremaworte, no. 885 .

${ }_{3}$ Probably so to be read, though the bird-sign actually employed is 3 and not tiw.

${ }^{4}$ See above, p. 249. Since the first part of this article was in print, I have noticed that the inscription on the Carnarvon scarab, p. 131, under E, ought probably to be translated: "The-Castle-of-RamessesBeloved-of-Amün-Beloved-like-Tüm on the west of the 'Ity-waters." Where this temple was situated is unknown. There is as yet no reason to think that a town of Ramesses was built around it.

${ }^{5}$ Brugsch, Dictionnaire Géographique, p. 197.

${ }^{6}$ Naville, Goshen, p. 26 ; ID., Mound of the Jew, pp. 24-5; Petrie, Hyksos and Israelite Cities, p. 65. It is true that the few fragments of inscription found by Professor Naville at Belbês did mention the goddess Bast and places belonging to the Bubastite nome; but this does not prove that Brst is Belbês.

7 The fictitious writer of the satirical letter contained in Pap. Anastasi $I$ is of mythological name and parentage; he was called Hori, son of Onnophris of Abydos, "born of Tewosiet ("the powerful," i.e. Isis) in the district of Brst, the chantress of Bast in Field-of-the-God." See GARdiner, Egyptian Hieratic Texts, vol. I, p. 5 and p. 7*, notes 2 and $3 . \quad{ }^{8}$ BrUGSCH, Dictionnaire Géographique, p. 1328.

9 Bénédite, Le Tombeau de Neferhotpou, Pl. III, in Mémoires de la Mission Française, vol. v. 
from the passage in Pap. Harris which gave rise to this discussion of Brst, Pr-Brst is that "The-Waters-of-the-Sun" was the name of the Nile-arm that ran past Bubastus. The designation is a natural one, for the Bubastite branch left the main river (the "Great River") near Heliopolis, to whose god it appears to owe its name. We have only to suppose that "The-Waters-of-the-Sun" was the term applied to the entire Bubastite branch in order to understand how that term could be used in connection with Pi-Ralmesse. Pi-Ra ${ }^{\prime}$ messe was near the sea, and accordingly lay near the mouth of the Bubastite Nile-arm. But the Bubastite Nile-arm debouched in the Pelusiac mouth, and consequently we are again led back to the conclusion that Pi-RaCmesse is Pelusium. With this view of "The-Waters-of-the-Sun" agrees the fact that the entire region lying along this branch seems to have been called P3-rd-n-ps-RC, "The-Border-of-the-Sun"; a prince of this region has left a statue at Șaft elHenneh". Brugsch rightly conjectured that "The-Border-of-the-Sun" represented the eastern margin of the Delta just as Border," was the name given to its western margin"; in two places $\int_{\text {II I }}^{D} P$-rd-i3bty, "The-Eastern-Border," is mentioned ${ }^{4}$, and either is identical with "TheBorder-of-the-Sun" or else has a wider extension but includes it. Other place-names in the same general region into the composition of which $R c, P 3-R c$ enters are

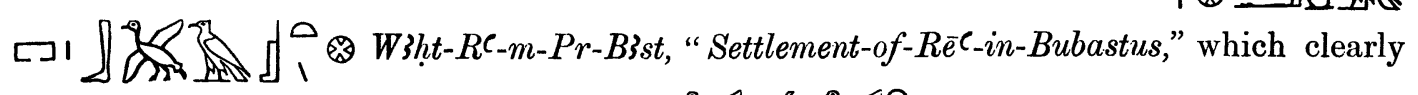
cannot have been far from Bubastus", and of-the-Sun," attested by an inscription of Takelothis II as being somewhere in this vicinity 6 .

Thus the identification of Pi-Racmesse with Pelusium is further suggested by its situation on the banks of "The-Waters-of-the-Sun," a good wine-growing district, as the

1 Annales du Service, vol. XI, pp. 142-4.

2 It had military officers of its own, who were apparently subordinated to the commandant of Theku in the Wâdy Tamilat, Pap. Anastasi V, 25, 3. 4; their province of action must have been the nome of Arabia and the parts east of it. See also Inscriptions of Sinai, no. ${ }^{\circ} 295$.

3 BRugsch, Dictionnaire Géographique, pp. 439-40, 1247-8. For “ The-Western-Border," see Mariette, Monuments Divers, 277, and several other passages that all throw light on its extension. From Pap. Harris 77, 1 it is clear that it extended from Memphis in a north-westerly direction. In the accounts of Meneptah's defeat of the Libyans it is twice said that this occurred in "The-Western-Border" viz., on the Athribis stele, Zeitschrift für ägyptische Sprache, vol. xxI [1883], p. 66, and in a new fragment of the Karnak text, Recueil de Travaux, vol. xxxI, p. 179 ; and it is clear that it is in this sense that ps $r d$ is to be understood in 1.30 of the Karnak inscription, where the locality is more definitely specified under the name Pr-irw. In Pap. Bologna 1094, 7, 3 the writer of a letter addresses his prayers to the gods of "The-Western-Border," and later on (7, 9), when narrating events of local interest, mentions Pr-'Irw. No doubt Golénischeff is wrong in identifying this Pr-irw with a place south of Herakleopolis Magna mentioned in his hieratic glossary (Zeitschrift für ägyptische Sprache, vol. xL [1902-3], p. 102); nor is the name to be read $P r-i r-s p s$, and Brugsch's identification with Prosopis therefore falls to the ground.

4 Pap. Harris 500, verso 5, 2; Spiegelberg, Rechnungen, p. 44.

5 Pap. Anastasi V, 22, 2 ; 27, 5.

6 Recueil de Travaux, vol. xviII, p. 53. 
potsherds from the Ramesseum indicate. Pelusium is not mentioned by the classical writers as especially famous for its wines, but as we have seen, the wine of Śinw, Swn enjoyed a high repute in Pharaonic Egypt from the very earliest times. That Pi-Ra ${ }^{2}$ messe was in the centre of a great wine-growing region is proved by the praise bestowed upon the famous vineyards of Kenkēme; for these see nos. 15, 26 and perhaps no. 37, together with the notes thereupon. Pelusium was also a great place in Graeco-Roman times for the drying and salting of fish, and for the cultivation of lentils; in the Revenue papyrus it is a commercial port for oil rivalling even Alexandria. These conditions generally agree well with the account of Pi-Ralmesse given in Pap. Anastasi III (no. 15).

Strabo (c. 803) says that Pelusium was more than twenty stades from the sea, i.e. some $2 \frac{1}{4}$ miles, a distance which corresponds pretty well to modern conditions. Lying beside the Bubastite Nile-arm it was to all intents and purposes a sea-port. It seems not impossible-though for this we have no very tangible evidence-that the actual harbour

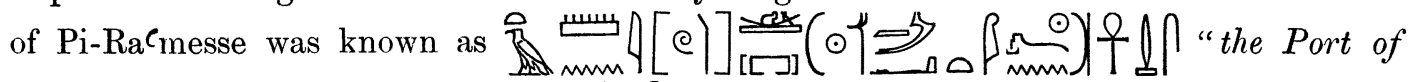
Usimarēe-setpenre e" or simply " the Port." In a model letter its writer describes how he sought two boats: "I went southwards upon the edge of the water (the sea-shore?) and found them in the Port of Usimare $\bar{e}^{-}$-setpenre $\bar{e}$ in charge of the Fanbearer Rekhy." On several wine-jars discovered in the Ramesseum mention is made of "wine of the vineyard of the Castle-of-Usimarēe-setpenrē ${ }^{-}$-in-the-House-of-Amun (i.e. the Ramesseum) on the west of the Port"," and once the entry "much oil from the Port" occurs in a list of imported oils and the like ${ }^{3}$. Whether this guess (for it is nothing more) be true or not, it is now familiar to us that Pi-Racmesse was considered as a port (see nos. 15, 16), and may therefore well have been Pelusium.

The last reason to be invoked in favour of the position here accorded to $\mathrm{Pi}-\mathrm{Ra}{ }$ messe is its suitability from a historical point of view. The Hyksos had established themselves in a fortress-town midway between Palestine and the main valley of the Nile, and had thus created a precedent which Ramesses II may well have copied. In the flourishing period of the Eighteenth Dynasty the Pharaohs were powerful enough, and sufficiently little apprehensive of Eastern aggression, to rule their Syrian Empire from Thebes and Memphis. In the Nineteenth Dynasty, however, that Empire was no longer secure, but required careful watching from a central position; therefore Ramesses II, or it may even have been his grandfather Ramesses $\mathrm{I}^{4}$, founded a new Residence near Pelusium, much as

1 Pap. Leyden 348, 8, 6-7, cf. also 9, 2; "edge" (spt) here is an emendation, but a practically certain one.

2 Spiegelberg, Hieratic Ostraka, nos. 239, 262, 299.

3 Anastasi IV, 14, 4.

4 In 1913 M. Legrain discovered near the pylon of Haremhab at Karnak two statues dating from that reign and belonging to a Vizier Pracmesse son of Sētoy (Annales du Service, vol. xıv, pp. 29-38); in publishing the find M. Legrain makes the very probable suggestion that this Vizier was none other than Ramesses I. Recently (op. cit., vol. xvII, p. 168) M. Daressy has called attention to the title borne by him "overseer of the river-mouths" and also to the name of his father, which is simply that of the god Sêtekh found on the monuments of Tanis. Hence M. Daressy concludes that the family of the Ramessides originated in these parts. This notion appears to me by no means improbable, though, from what we have seen, all that M. Daressy says about the connection between Sētekh and Tanis must be transferred to the site of Avaris and Pi-Ra' ${ }^{C}$ messe near Pelusium. 
Peter the Great, needing to guard his Baltic provinces, removed his capital from Moscow to St Petersburg. Later, the Egyptian hold over Syria became so insecure that the Delta capital was withdrawn to Tanis. Such appears to have been the general sequence of events.

From the number of serfs of Amūn resident in Pi-Ra ${ }^{C}$ messe under Ramesses III (no. 27) we learn that it must have been a town of considerable size. The officials and domestics of the Court will certainly have been numerous, and since the place became a great administrative centre it must undoubtedly have ranked among the larger cities of Egypt, though never rivalling with Thebes, Memphis or Heliopolis. It owed its prominence to the favour bestowed upon it by all the Pharaohs from Ramesses II to Ramesses III, as well as to its strategic importance.

So far as the Biblical city of Raamses-Rameses is concerned, the plan of this essay has been less to solve the problem than to provide the material for its solution. An estimate of the historical value of the Exodus narrative obviously lies outside the province of the Egyptologist; nor indeed can our quest be so extended as to include an exhaustive revision of the geography of the Exodus-route in the light of the Egyptian sources. Nevertheless, the conclusions here reached do seem to provide a basis for further deductions. These will be suggested in a tentative way, and it will remain for Biblical students to reject or to confirm them.

Of the towns deriving their name from the Pharaoh Ramesses the foregoing investigations have elicited only two which could with any plausibility be claimed as the original of the store-city mentioned in Exodus i, 11 . One is the Residence-city at or near Pelusium, and the other the station named "The-Dwelling-of-Ramesses-Beloved-of-Amūn" on the high-road from Thel (Sile) to Raphia (above p. 132, under H) ${ }^{1}$. The latter has been up to the present without an advocate, and is likely to remain so; it seems to have been a place of no great size or importance, and its name contains in its composition an unusual and characteristic element, "The-Dwelling" $\left(t 3 c^{c}\right)$, the omission of which to yield the shortened place-name "Raamses" is highly improbable. On the other hand there is no difficulty in identifying the name of the Biblical Raamses with that of the Ramesside Delta Capital (see above, p. 138). The issue before us may, therefore, be defined : either Raamses-Rameses of the Bible is the Residence-city of the Ramessides near Pelusium, or else it is a town unknown to the Egyptian monuments, the existence of which is merely postulated.

In order that the problem may be the more clearly focussed, the various O.T. passages in which the name of Rameses or Raamses occurs are here set forth seriatim, with a few supplementary and explicative notes.

(a) Genesis xlvi, 28-29: "And he (Jacob) sent Judah before him unto Joseph, to shew the way before him unto Goshen; and they came into the land of Goshen. And Joseph made ready his chariot, and went up to meet Israel his father, to Goshen."

The Hebrew text does not mention the name of Rameses ; but the LXX presents the version: "And he sent Judah before them to Joseph to come to meet him at Heroonpolis into the land of Ramesses

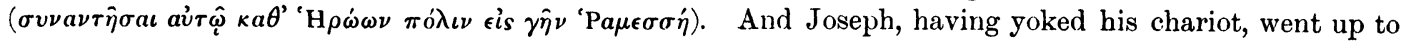

1 There is no evidence whatever that the temple "The-Castle-of-Ramesses-Beloved-of-Amün-Belovedlike-Tüm-on-the-west-of-the-'Ity-waters" on the Carnarvon scarab (p. 131, E and p. 258, footnote 4) represents a town of Ramesses, so that this alternative may be left out of account. 


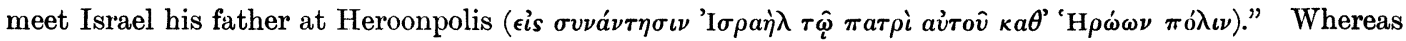

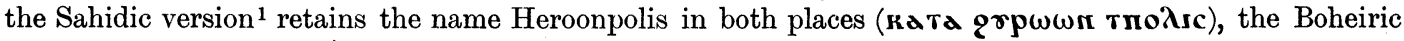
version has qa neөw and eпc sine

The LXX presents a twofold expansion of the phrase "into the land of Goshen": first the words "at Heroonpolis" are of the nature of a topographical gloss based on Exodus i, 11 (below c), and second, "into the land of Ramesses" is a harmonistic rendering derived from xlvii, 11 (below $b$ ).

Josephus, Arch. Jud., ed. NABER, II, 184, says that the meeting-place of Jacob and Joseph was Heroonpolis.

(b) Genesis xlvii, 11 : "And Joseph placed his father and his brethren, and gave them a possession in the land of Egypt, in the best of the land, in the land of Rameses, as Pharaoh had commanded."

The command of Pharaoh (xlvii, 6) actually was: "in the land of Goshen let them dwell"; clearly "the land of Rameses" here is synonymous with "the land of Goshen," a standpoint that was in the mind of the LXX translators of xlvi, 28-29 (above $a$ ). Biblical chronology assigns the king under whom Joseph lived to the Hyksos period; be this as it may, the phrase "the land of Rameses" must in any case be a crass anachronism, or, as the commentators more politely say, is used "proleptically."

The Targum of Palestine has: "And Joseph brought his father and brethren to dwell, and gave them a possession in the land of Mizraim, in a goodly part of the country, in the country of Pilusin, as Pharaoh had commanded." Targum Jerushalmi : "Pelusim"; it is quite evident that Pelusium is intended.

Josephus, Arch. Jud., ed. NABER, II, 188, states that the place where Jacob was given leave to dwell was Heliopolis.

(c) Exodus i, 11: "And they built for Pharaoh store cities, Pithom and Raamses."

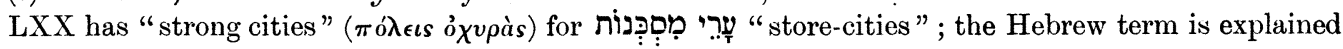
to mean cities for provisions, materials of war, etc., possibly also cities used as trade emporia. LXX

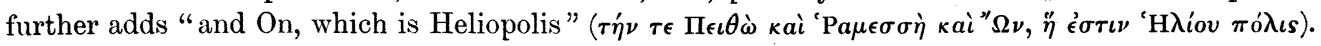

The Targum of Palestine paraphrases: "And they builded walled cities to become Pharaoh's treasureplaces, Tanis ${ }^{2}$ and Pilusin"; the Targum of Jerusalem gives the names in the same form.

(d) Exodus xii, 37: "And the children of Israel journeyed from Rameses to Succoth."

This follows immediately upon the smiting of the first-born, upon the injunction to depart given by night to Moses and Aaron, and upon the spoiling of the Egyptians by the taking of their gold and silver.

Targum of Palestine: "And the sons of Israel moved forth from Pilusin towards Succoth."

(e) Numbers xxxiii, 3-6: "And they journeyed from Rameses in the first month...on the morrow after the passover....And the children of Israel journeyed from Rameses, and pitched in Succoth."

Targum of Palestine: "Pelusin" for Rameses in both cases ; so too Targum of Jerusalem.

To these passages must be added from the Apocrypha:

(f) Judith i, 7-10: "And Nebuchadnezzar king of the Assyrians sent unto all that dwelt in Persia,..., and to all that were in Samaria and the cities thereof, and beyond Jordan unto Jerusalem, and Betane, and Chellus, and Kadesh, and the river of Egypt, and Tahpanhes, and Rameses, and all the land of Goshen, until thou comest above Tanis and Memphis, and to all that dwelt in Egypt, until thou comest to the borders of Ethiopia."

"The land of Goshen" here evidently means the Delta, and is opposed to Egypt, i.e. Upper Egypt.

No great attention need be paid to the passage in Judith, the writer of which seems simply to have chosen some of the commoner Egyptian place-names familiar to him from the canonical scriptures; we may note, however, in passing, that Rameses is distinguished from Tanis. It is upon the other five passages that tradition and modern exegesis alike have based their hypothesis of a town of Ramesses in the Wâdy Tûmîlât. So far as tradition is concerned, the only quite definite evidence of the existence of such a view is

1 See Mission Archéologique Française, vol. vi, p. 26.

2 It is curious that the Targum of Palestine consistently calls Poti-phera "the rabba of Tanis," while the Hebrew original has "priest of On" (Gen. xlii, 45, 50; xlvi, 20). See below, p. 265, footnote 2. 
a passage in the narrative of the Abbess Aetheria, the pilgrim lady from Gallia Narbonensis, the account of whose travels in Biblical lands (533-540 A.D.) is preserved in the Library of Arezzo. On her return journey from Sinai to Egypt via Clysma (Suez) and the Wâdy Tûmîlât she visits in turn the supposed sites of Migdol, Baal-zephon, Etham, Succoth, Pithom, Heroonpolis, Rameses and Arabia, the last of which she says is a town in the land of Goshen'. The two places Heroonpolis and Arabia are not alluded to in the Hebrew text of the Bible, but are derived from the Septuagint, on which, consequently, Aetheria's narrative is largely dependent. In both cases Aetheria, or the authorities upon whom she relies, has gone astray in her interpretation; for she distinguishes Heroonpolis from Pithom, whereas it was precisely the identity of those two places, as we shall see,

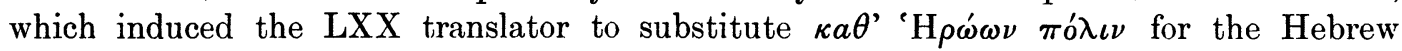
"Goshen" in Genesis xlvi, 28-9 (above $a$ ); and again, she inverts the relationship of the terms in the expression "Geshem of Arabia" used by the LXX for Hebrew "Goshen" in Gen. xlv, 10 ( $c f$. xlvi, 34), interpreting Arabia as a city and Geshem as a land, the exact antithesis of the Greek translator's intention. Now both the city of Heroonpolis and that of Arabia were in Aetheria's day populous places, bearing just those names; Heroonpolis she describes as a large village, with a church, saints' tombs and many monasteries ${ }^{2}$, and Arabia we know to have been the seat of a bishopric. Excavation has shown that Heroonpolis was, at all events, not very far from Tell el-Maskhûțeh; and it is practically certain that Pithom and Heroonpolis are identical ${ }^{3}$. The town of Arabia is stated by the Oxford list of bishoprics $^{4}$ to be the same as Fâkûs, otherwise one would have sought for it a position nearer, like Safț el-Henneh, to the mouth of the Wâdy Tînîlât. These two towns, accordingly, are the fixed points in Aetheria's narrative. She may have concluded from Exodus i, $11(c)$, that Pithom and Rameses were towns not very far apart from one another ; she will certainly have argued from the words "at Heroonpolis into the land of Ramesses" in Genesis xlvi, 28 (LXX) that Rameses and Heroonpolis were close together; finally, since Rameses was the starting-point of the Exodus (passages $d, e$ ), this will have been in the land of Goshen, i.e. in the neighbourhood of the town of Arabia. Such considerations are enough to account for all Aetheria's learning on the subject of the town of Rameses. What she has to tell us about it is as follows:

"But from the town of Arabia it is four miles to Ramesses. We, in order to arrive at Arabia, our stopping-place, had to pass through the midst of Ramesses, which town of Ramesses is now fields, so much so that it does not possess a single habitation. It is true that it is visible, since it both was huge in circuit and had many buildings; for its ruins, however tumble-down they may be, appear endless even to this day. But now there is nothing there saving only one huge Theban stone, in which two statues have been carved out, huge ones, which they say belonged to the holy men, i.e. to Moses and Aaron, for they say the children of Israel placed them there in their honour $5 . "$

1 "Ac sic ergo exeuntes de Hero pervenimus ad civitatem, quae appellatur Arabia, quae est civitas in terra Jesse." I quote from the extracts of the pilgrimage printed in Küthmans, Die Ostgrenze Ägyptens, pp. 6--10.

2 "Heroum autem civitas...nunc est come, sed grandis, quod nos dicimus vicus. Nam ipse vicus ecclesiam habet et martyria et monasteria plurima sanctorum monachorum."

3 See the appended "Note on Pithom and Heroonpolis," below, p. 268.

${ }^{4}$ See De Rodgé, Géographie de la Basse Égypte, p. 155. On this question and on Goshen generally, see further, Journal of Egyptian Archaeology, vol. v, pp. 218-223.

5 "De Arabia autem civitate quattuor milia passus sunt in Ramessen. Nos autem, ut veniremus ad mansionem Arabiae, per media Ramesse transivimus, quae Ramessen civitas nunc campus est, ita, ut nec unam habitationem habeat. Paret sane, quoniam et ingens fuit per girum et multas fabricas habuit; 
Not much importance need be attached to this passage, which, be it said in passing, is a very fair sample of the pious lady's literary style. Its historical value is no greater than that of the early Jewish tradition which, as has been seen in the comments on passages $c$, $d$, e, identified Raamses-Rameses with Pelusium. The latter identification may perhaps seem a strange coincidence, in view of the fact that the Ramesside capital of Pi-Ralmesse has been located at or near Pelusium. Nor, indeed, is it quite impossible that there may be some causal connection here, but its roots are hidden and can no longer be unearthed. For the present, at least, we must measure the value of this Targumic tradition by that of the parallel identification of Pithom with Tanis (see under $c$ ).

Going back some centuries to the time of the Septuagint translation, we learn from the variation between the Hebrew and Greek texts in $(a)$ that the translators had made an effort to interpret the Exodus narrative as a consistent whole, and had formed at least some sort of conception of the Exodus geography. It is impossible to account for the replacing of "Goshen" in the Hebrew text by the Greek "at Heroonpolis" except by regarding this as due to the influence of Exodus i, $11(c)$, and to the knowledge that Heroonpolis was merely the Greek name of Pithom. Similarly, the addition "into the land of Ramesses ', resulted from the desire to connect the reference to Goshen in this passage with that in Genesis xlvii, 6, the latter being replaced in the Hebrew text a few verses later (xlvii, 11) by "in the land of Rameses" $(b)$. Since the LXX translator probably understood this phrase to mean "in the land of (the town of) Rameses," as modern commentators, whether rightly or wrongly, have for the most part done", he is likely to have interpreted his own combination of words "at Heroonpolis into the land of Rameses" to mean that the town of Raamses-Rameses was not far from Pithom. But, as we see, this conclusion was the outcome of a harmonistic combination of the data of the Hebrew text, and represented no independent tradition demanding to be taken into account by ourselves.

A still earlier tradition, which is persistently ignored by students of the Exodus times, is that of the Psalmist who sang of the "marvellous things" which God did "in the land of Egypt, in the field of Zoan" (lxxviii, 12), "how he set his signs in Egypt, and his wonders in the field of Zoan" (lxxviii, 43). Here we have a quite definite view, at all events, that the scene of Moses' activities was the extreme north of the Delta. Are we to regard the reference to "the field of Zoan," on which see above, pp. 200, 248, as a reminiscence of the times of the Twenty-first Dynasty, when Tanis was the seat of the Lower Egyptian government? Or is the phrase a genuine recollection of the fact that the Ramesside Pharaohs, under whom Moses lived, made their Delta residence near Pelusium, a place situated in the nome with which the region called "the field of Zoan" was intimately connected?

To turn now to modern views: the prevalent notion of a city of Ramesses within and near the mouth of the Wâdy Ṭumîlât owes its existence to the same kind of standpoint as that which the LXX translator held, and partly indeed to his specific contributions to the problem, namely, the introduction of the names "Heroonpolis" and "Geshem of Arabia." The fixed point around which the whole theory circles is the known position of PithomHeroonpolis in the Wâdy Țûmîlât (this is now sufficiently confirmed by the excavations at

ruinae enim ipsius, quem ad modum collapsae sunt, in hodie infinitae parent. Nunc autem ibi nichil aliud est nisi tantum unus lapis ingens thebaeus, in quo sunt duae statuae excisae, ingentes, quas dicunt esse sanctorum hominum, id est Moysi et Aaron, nam dicent, eo quod filii Israhel in honore ipsorum eas posuerint."

1 Max Müller (s.v. "Rameses" in Encyclopaedia Biblica, col. 4012) prefers "to understand Rameses here as having preserved the original sense, namely, that of a royal name." 
Tell el-Maskhûteh). It is probably tacitly assumed that, since the Israelites, being confined to the land of Goshen, cannot have built cities outside it, the land of Goshen must have included the Wâdy Ṭûnîlât, where Pithom was situated $(c)$; and Raamses, which is coupled with Pithom, is accordingly in the same region too. This is supported by $(b)$, where "in the land of Rameses" corresponds to "in the land of Goshen" a few verses earlier, as well as by the LXX version in (a) already sufficiently discussed. Lastly, when the Egyptians set out upon their journey to Canaan, their starting-point is Rameses $(d, e)$ which must, accordingly, have lain quite at the Egyptian end of the Wâdy Ṭûmîlât.

All this is good logic, and would be valid argument if the narrative of the sojourning in and departure from Egypt were a single homogeneous account, to be regarded as sound historical evidence. It is easy to show, however, that the entire story is clothed in a legendary form, and legend has no care for strict topographical exactitude. Modern critics have pointed out that two irreconcilable views underlie the earlier chapters of Exodus : in some places it is assumed, as throughout Genesis, that the Israelites were living apart in the land of Goshen; elsewhere, on the other hand, it is unmistakably implied that they were dwelling in the midst of the Egyptians ${ }^{1}$. If Moses and the Israelites were separated off in the Wâdy Țûmîlât, how could Moses "rise up early in the morning and stand before Pharaoh" (Exodus viii, 20)? Or how could his cradle have been deposited among the flags in the river, to be found by Pharaoh's daughter (Exodus ii, 1-10)?

It having been established by our researches that the Delta capital of the Ramessides was at Pelusium, or at all events nowhere near the Wâdy Ṭ̂mîlât, we may feel convinced that there, if anywhere, must have occurred the finding of Moses as a babe and his later controversies with Pharaoh. Thus, those who view the Exodus narrative as authentic history can hardly refuse to deduce from the passages just quoted that at least a part of the Israelites, and among them Moses, dwelt at Pi-RaCmesse. Nor indeed is there in the Biblical passages referring to Raamses-Rameses anything seriously out of keeping with this conclusion. The passage Exodus i, $11(c)$ does not necessarily imply that Raamses was near Pithom, and indeed the LXX translator, whose tendencies elsewhere are all in favour of harmonizing the Exodus geography, here adds a third town Heliopolis that was far away from Pithom". The phrase "the land of Rameses" in $a(\mathrm{LXX})$ and $b$ is puzzling, and in

1 See Driver on Exodus viii, 22, in the Cambridge Bible for Schools. For the view that the Israelites were still in Goshen he quotes viii, 22: "And I will sever in that day the land of Goshen, in which my people dwell, that no swarms of flies shall be there"; also ix, 26 : "Only in the land of Goshen, where the children of Israel were, was there no hail." For the opposite view, $c f$. iii, 21-22: "And it shall come to pass, that, when ye go, ye shall not go empty : but every woman shall ask of her neighbour, and of her that sojourneth in her house, jewels of silver, and jewels of gold, and raiment"; and the similar passage, xi, 2. Driver represents the view of the Israelites' confinement to Goshen as belonging only to $J$, while $\mathrm{E}$ pictures them as living side by side with the Egyptians. But e.g. xii, 23 ("For the Lord will pass through to smite the Egyptians; and when he seeth the blood upon the lintel, and on the two side posts, the Lord will pass over the door") presumes the standpoint attributed to $\mathrm{E}$, but nevertheless is assigned to $\mathrm{J}$.

2 On the origin of this addition a guess may be hazarded. Heliopolis was the chief home of the deity Tūm, and was therefore a Pi-tūm "House-of-Tum." The mention of Heliopolis will have arisen, accordingly, as a gloss on Pithom. Some confirmation of this view may be found in the coincidence that the Targum gives Tanis as the rendering, not only of Pithom here, but also of On in the phrase "Potiphar, priest of On," see above, p. 262, footnote 2 ; how the Targumic commentator came by the identification of these places with Tanis is unknown, but it is significant that they were associated in his mind. As for Josephus' identification of Goshen with Heliopolis (see above on $b$ ), it was probably due to the considerations (1) that Jacob would wish to live near Joseph, and (2) that Joseph, being married to the daughter of a Heliopolitan priest, was presumably domiciled at Heliopolis.

Journ. of Egypt. Arch. v. 
any case contains a grave anachronism; in Genesis xlvii, 11 it clearly corresponds to "the land of Goshen " in $v .6$, but the variation of that name at such close quarters is so unnatural and incongruous, that it is difficult to do otherwise than infer that two discrepant sources have here been clumsily combined, in which case, of course, the term "land of Rameses" would not necessarily be co-extensive with "land of Goshen." As regards $d$ and $e$, it would now become clear why the children of Israel, starting out on their journey, are said to have journeyed from Rameses-it is because that was the place where Pharaoh dwelt and persecuted them; the only difficulty in these passages is that, if Succoth is Theku towards the eastern end of the Wâdy Tûmîlât ${ }^{1}$, this is more than one day's march from the Delta Capital.

If we take the opposite point of view, namely that the Exodus story, whatever nucleus of truth it may contain, has come down to us in purely legendary garb, we shall not feel disposed to insist upon the distance between Rameses and Succoth, nor to equate "the land of Rameses" exactly with "the land of Goshen." On the contrary, our verdict will be that the Biblical town of Raamses-Rameses keeps alive a dim recollection of the very city where the Pharaohs of the Oppression and of the Exodus actually resided.

To sum up: whether or no the Bible narrative be strict history, there is not the least reason for assuming that any other city of Ramesses existed in the Delta besides those elicited from the Egyptian monuments. In other words, the Biblical Raamses-Rameses is identical with the Residence-city of Pi-Ralmesse near Pelusium. And at this point we shall remember that there are two traditions, though both of uncertain value, which are in accord, or can be construed as in accord, with our conclusion: these are the traditions of the Psalmist and of the Targum, both discussed above.

It may be objected: this fine-spun argument is all very well in its way, but has not the Biblical town of Raamses-Rameses, in point of fact, been discovered by Professor Petrie at Tell er-Retâbeh, eight and a half miles westward of Tell el-Maskhûteh ${ }^{2}$ ? The evidence for the identification proves, on close examination, to be more than scanty ${ }^{3}$. A temple-wall was found on which Ramesses II is seen slaughtering prisoners before "Tūm, lord of Thu (sic)"; "Theku" ought here to be read, as Professor Petrie has himself seen, for among the few other Ramesside temple-fragments discovered there was one mentioning Theku, as well as part of a door-jamb from the tomb of the contemporary commandant of Theku. The remaining finds were a stele of Ramesses II recording the defeats

1 The identity of תִ Succoth with $\underline{T} k w$ (see below p. 265, in the appended note) was first proposed by Brugsch (Zeitschrift für ägyptische Sprache, vol. xIII (1875), p. 8); the rendering of the first two consonants is correct, but as regards the termination of the Hebrew name it has to be assumed that this has been altered in accordance with a popular etymology sukkoth=" "huts." The identification is now pretty generally accepted and may stand; but there is no longer much reason for it beyond the general correspondence of sound, and the fact that Theku was situated between Egypt and the desert and consequently corresponds passably well with the Exodus data. It may be here noted that in the hieroglyphic lists of nomes Theku is the capital of the VIIIth nome of the Eastern Harpoon. In Greek times this nome is merged in that of Arabia, except in the case of Strabo 805, who places a nome called Phagroriopolites in this region. On the VIIIth Lower Egyptian nome in general see Küтнмans, op. cit., pp. 27 foll.

2 Op. cit., p. 28, Professor Petrie says eight miles, but in Egypt and Israel, p. 33, he says ten; the distance as shown by the Egyptian Survey map 1:50,000 is $8 \frac{1}{2}$ miles.

3 See Petrie, Hyksos and lsraelite Cities, Pls. XXVIII-XXXVI c, with pp. 28--34. 
mflicted on the Shōsu (Asiatic Beduins)'; a dyad in red granite representing Ramesses II and the god Tūm; foundation deposits of Ramesses III; and various scarabs and minor objects from burials of the Ninth Dynasty onwards. There is nothing here to suggest that the place was called Raamses, and indeed Professor Petrie's commentary shows that the identification is based on erroneous assumptions. He writes": "All of these discoveries exactly accord with the requirements of the city of Raamses, where both the second and third kings of that name are stated to have worked, and where a store-city was built by the Israelites along with that of Pithom, which is only eight miles distant. The absence of any other Egyptian site suitable to these conditions, which are all fulfilled here, makes it practically certain that this was the city of Raamses named in Exodus." In the first sentences Professor Petrie is obviously referring to the Residence-city, which we now know to have been situated elsewhere; and further on it is unjustifiably concluded from Exodus i, 11 that Raamses and Pithom were close to one another. No additional argument is offered beyond the daring suggestion that the dyad of Ramesses II and Tūm is none other than Aetheria's "lapis ingens thebaeus, in quo sunt duae statuae excisae, ingentes, quas dicunt esse sanctorum hominum, id est Moysi et Aaron ${ }^{3}$."

We may thus feel certain that Tell er-Retâbeh is not Raamses, since there is no serious evidence that a town of Ramesses ever existed in this region. Its ancient name is not known to us, unless it, rather than Tell el-Maskhûteh, be the true site of Pithom ${ }^{4}$; but our incertitude on this point need not trouble us, for there are several places in the Wâdy Ṭ̂umîlât still to be identified, and the topography of the whole region is still regrettably obscure.

\section{Note on Pithom and Heroonpolis.}

The positions of Pithom, Heroonpolis and Theku (the supposed prototype of Succoth, see above, p. 266, footnote 1) are sufficiently fixed for the purposes of this article, but I am the more desirous to review the problems connected with them as I can no longer adhere to my statement above, p. 128, that the excavations of Professor Naville at Tell el-Maskhateh finally settled the question of Pithom, which was found to be identical with that site. Most of the issues are discussed elaborately, though not always convincingly, in Naville, The Store-city of Pithom, pp. 4 foll. The old view of Lepsius, reiterated Zeitschrift für ägyptische Sprache, vol. xxI (1883), pp. 41-53, to the effect that Pithom lay near Tell Abu Suleimân, while Heroonpolis-Raamses was to be sought at or near Tell el-Maskhateh, reposed (1) on the identification of Pithom with Thou in the Antonine Itinerary, the place where the road via Daphnae to Pelusium

1 This stele, as is not unusual in the Ramesside period, consists merely of royal names and epithets, of which the concluding words are very interesting. They run: $c$

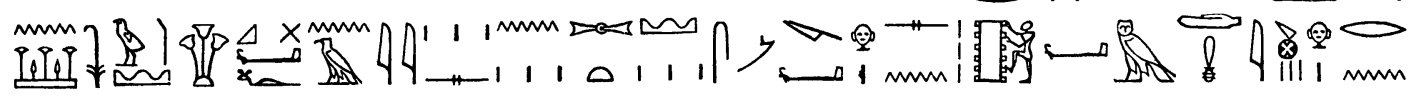
(n) In Professor Petrie's text this is translated: "(of the) great enemies in the land of the Bedawyn he plundered their hill fortresses, slaughtering their faces, and building in cities upon which his name is to eternity"; the comment is added that "this allusion to building in the various cities called after Ramesses suggests that this city was one of such-that is, Raamses." The first phrases are simple, but are mistranslated by Professor Petrie; at the end it seems necessary to bring the words $k d m$ dmiw somebow into connection with the Asiatics (Shōsu), and it is therefore likely that -sn "their" has been omitted. Accordingly I translate : "making a great massacre in the land of the Shōsu; he plunders their hills, and slaughters upon them; building in (their) cities in his (own) name for ever." The reference, then, would be to the annexation of towns in Palestine, not to the building of towns of Ramesses in Egypt.

2 Op. cit., p. 28.

4 See below, the appended note.

$35-2$ 
branched off from the Heliopolis-Hero-Serapiu-Clysma (Suez) road, and (2) upon Herodotus ii, 158 引̉kraı $\delta \dot{\boldsymbol{\epsilon}}$

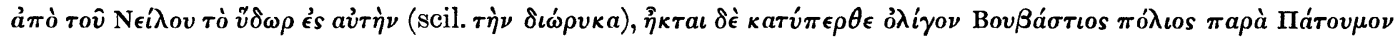
$\tau \dot{\eta} \nu$ 'A $\rho a \beta i \eta \nu \pi$ ó $\lambda \iota \nu$. As to (1), the suggestion would hardly have arisen but for the ill-supported various reading Thoum, which is certainly to be rejected; as to (2), this much-disputed passage (see NavilLE, op. cit., pp. 34-9) is quite plausibly taken by Dillmann and others to mean that the water of the canal was drawn away from the Nile not at, but alongside, Pithom, which may thus be at some distance from the point of junction. The view of Brugsch that Pithom was near Lake Menzaleh hangs together with his whole Exodus theory, some portion of which (the identity of Tanis and Raamses) has been disproved in the present article. At the present time the only scholar who appears to disagree with Prof. Naville's conclusions is M. Daressy, see Bulletin de l'Institut Égyptien, vol. 5 (1911), p. 3. The ground may be cleared by considering the relations of Pithom and Heroonpolis; the identity of these two places may be proved both (1) on traditional and (2) on linguistic grounds. (1) The Boheiric version of Genesis xlvi, 28 has Pethōm for LXX Heroonpolis, see passage $a$ on p. 261 ; and as I have shown (p. 264), Heroonpolis in the LXX translation was due simply to the presence of Pithom in Exodus i, 11. (2) The variants Eron (Geogr. Rav.), Ero (inscriptions from Maskhûteh), Ero and Hero (Aetheria) and 'H $\omega \dot{\omega}$ (Steph. Byz.) suggest that the original Greek name of the city was not Heroonpolis, but Heropolis, being derived from the name of an obscure deity "H $\rho \omega \nu$ of whom there was a temple at Magdola (see Grenfeld-Hunt, Tebtunis Papyri, no. 80, introduction); and this is confirmed by the existence, in the translation of the (Flaminian?) obelisk preserved by Ammianus Marcellinus, of a royal epithet "H $\rho \omega \nu$ os viós, which, in spite of the caveat entered by Sethe apud ERMan, Die Obeliskenübersetzung des Hermapion, p. 253, footnote 3, in Sitzb. d. Berliner Akad., 1914, IX, must surely correspond to $s \xi T m$ "son of Tūm" on the Flaminian obelisk. Thus the name Heropolis, later misunderstood as Heroonpolis, would originally have been a simple translation of Pithom. The explanations of the name Hero given by Lepsius (op. cit., p. 52) and Naville (op. cit., p. 10) are quite unsatisfactory. Now it cannot be denied that the evidence for the identification of Pithom-Heroonpolis with Maskhateh provided by Prof. Naville's excavations there is very formidable, seeing that they yielded not only hieroglyphic inscriptions mentioning Pithom, but also Latin inscriptions mentioning Ero. None the less, I incline to think that a still more likely view is that Pithom-Heroonpolis is identical with Tell erRețâbeh, $8 \frac{1}{2}$ English miles further westward. As has been already seen (p. 266), "Tum lord of Theku " was here worshipped, as at Maskhateh, so that theoretically, at least, Tell er-Rețâbeh can be regarded as a Pi-Tūm, Het-Tūm, "House of Tūm." The testimony of the hieroglyphic inscriptions from Tell el-Maskhateh shows indisputably that the commonest name of the place was Theku; Theku is mentioned there again and again, whereas Pithom is named only in two documents, namely the Bubastite statue, op. cit., Pl. 4, $\mathrm{A}, \mathrm{D}$, and the great stele of Ptolemy Philadelphus. Particularly clear evidence that Maskhateh was Theku is the invocation on the statue, op. cit., Pl. 5, A, to the priests "who enter into the temple of Tüm, the great living god in the midst of Theku" and the statement on the great Ptolemaic stele (the so-called Pithom stele, latest edition SETHE, Urkunden, II, 81-105) that this was erected "in front of Tūm, the great living god of Theku." On the same stele (op. cit., 93), when the return of the gods from Persia is being described, it is said that "the gods of Pithom and Theku (one can hardly translate "the gods of Pithom of Theku" as Prof. Naville does) came to rest there" (i.e. in Egypt), and this expression seems to imply that Pithom and Theku were distinguished. For the rest, the Pithom stele affords no evidence that Maskhateh was Pithom, for it describes the events that took place throughout the entire region, and if it records the establishment of offerings for Pithom (op. cit., 98), it does as much also for another place called Pr-Krht (op. cit., 104). Unfortunately the fact that Maskhâțeh can be shown to be Theku (or, as we had better say, the very heart of Theku, for we shall soon see that the term had a wider, as well as a narrower, significance) does not exclude the possibility that Maskhateh was also called Pithom; and this, indeed, is the standpoint that Prof. Naville takes. Still, there is evidence that "the fortress of Theku" was to the east of Pithom, for the famous passage Pap. Anastasi VI, ll. 54-7 states "we have finished causing the Beduin tribes of Edom to pass the fortress of Meneptah belonging to Theku towards the pools of Pithom [of] Meneptah belonging to Theku, in order to feed themselves and to feed their flocks." Here Theku appears as a wider term including Pithom, and with this fact we may compare the other that at Tell er-Retâbeh the deity worshipped is "Tüm, lord of Theku." Obscure as are the facts, it appears, then, that the most likely conclusion from the hieroglyhic data is that Maskhateh represents the "fortress of Theku" and that Tell er-Retâbeh represents Pithom. For further evidence of a fortress at Theku see the passage Pap. Anastasi V, $\mathrm{v}, 20,1$, where the words "the fortress" appear to refer to Theku in 19, 8. Also Theku possessed an idnw, the title usually borne by the "commandant" of a military station, cf. op. cit., 25, 2; 26, 1. Turning now 
to the Latin inscriptions discovered at Maskhateh, it is, indeed, awkward that two, and not merely one, should mention Ero; but on the other hand the simplest way of interpreting the obscure words on the milestone AB ERO IN CLVSMA VIIII is to understand this to signify "nine miles on the road from Ero to Clysma (Suez)," which would bring Ero westward within a few hundred yards of Tell er-Retâbeh ; it is curious that scholars should have failed to notice this easy way of reconciling Mommsen's rendering of the Latin words with Prof. Naville's protests against supposing that the milestone had been brought to Maskhateh from elsewhere (see on the whole question, NAvilue, op. cit., pp. 22-24). Turning now to the Antonine Itinerary, it will be seen that its data are at least as favourable to the view that Ero is Tell er-Retâbeh as they are to the accepted view that Ero is Maskhateh. Unhappily neither of the two places, Thou and Serapiu, with which Hero is there placed in direct relation, has as yet been certainly identified. Thou is placed by Prof. Naville (op. cit., p. 36) at Shugafìyeh near Tell el-Kebîr ; being, however, the meeting-point of the Pelusium-Daphnae-Heliopolis and the Clysma-Heliopolis roads, this is far too much to the east. Even CAbbâseh is too far eastward, and Șafṭ el-Ḥenneh would be a more suitable position. Now Saft is 30 English miles, as the crow flies, from Tell el-Maskhateh (the figures here given have been verified on the $1: 50,000$ Survey maps), while the Itinerary gives only 24 Roman miles as the distance between Thou and Hero. If, then, Thou was at or near Șaft, Tell er-Rețâbeh $\left(21 \frac{1}{2}\right.$ English miles) would be a most suitable position for Hero. The situation of Serapiu is even more doubtful than that of Thou; but if it is to be songht, as Prof. Naville supposes (op. cit., p. 25), at the foot of Gebel Maryam, where there are Roman ruins, this is only 12 English miles from Tell el-Maskhateh, whereas the Itinerary gives 18 Roman miles between Hero and Serapiu. In this case Tell er-Retâbeh is three to four miles too far away, but is, nevertheless more suitable than Maskhateh. It is true that the distances indicated by the Itinerary between Sile and Serapiu, on the one hand, and Serapiu and Clysma (Suez) on the other, seem rather to point to a position near the modern railway-station Serapeum (the identification has been inherited from the authors of the Description de l'Égypte); but against this must be set the fact that Serapiu was the place where the Pelusium-Clysma road parted from the road from Clysma via Hero and Thou to Heliopolis, and that from this standpoint a position near Gebel Maryam would be much more appropriate. In conclusion, we have seen (p. 263) that in Aetheria's time Ero had many monasteries and saints' tombs, besides a church. None of these seems to have been found either at Maskhateh or at Tell er-Retâbeh, so that archaeology here fails us; but the thick surrounding walls of Maskhateh (op. cit., p. 10) do suggest that this is "the fortress of Theku."

\section{VI}

In conclusion, it will be well to pass in review the results that have been attained. In the first section the cities of Ramesses other than the Delta Capital were enumerated and discussed. There were found to exist towns of Ramesses II near Naucratis (the modern Ramsîs), at Abu Simbel and at Derr, besides a small station on the Syrian road east of Kanțareh known as "The-Dwelling-of-Ramesses"; a town called after Ramesses III was situated in the north-western Delta. After a careful consideration of the name of the Delta Residence, which was "Pi-Ralmesse," often with the epithet "Great-of-Victories" or, after the death of Ramesses II, "The-Great-Soul-of-the-Sun-Horus-of-the-Horizon" ( $(\mathrm{II})$, the passages where this is mentioned were set forth in chronological order ( $\$ \mathrm{III})$. It was seen that Pi-RaCmesse was the regular northern abode of the Pharaohs from the reign of Ramesses II to Ramesses III, and was the seat of their Delta government. Hither the taxes were brought, and here were the great public offices. Pi-Ra ${ }^{2}$ messe possessed temples of Amūn, Rēe, Ptah and Sētekh, besides shrines of other lesser deities. The population was large, though doubtless it could not vie with that of Thebes or Memphis. The surrounding country appears to have been rich in produce of all kinds; in the neighbourhood of PiRalmesse were the celebrated vineyards of Kenkēme. In the fourth section the geographical

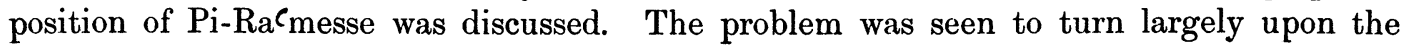
relations of the XIVth and XIXth Lower Egyptian nomes, and it was shown that Brugsch, 
in identifying the XIVth nome with the Tanites and the XIXth with the Sethroites, exactly reversed the truth. The association of $\mathrm{Pi}-\mathrm{Ra}{ }^{\prime}$ messe with a stretch of water called Ši-Hr "The-Waters-of-Horus" proved that Pi-Ralmesse was connected with the XIVth (Sethroite) nome, of which "Waters-of-Horus" is said to be the "river." From the identification of the Egyptian "Waters-of-Horus" with the Biblical Shihor it became evident that these names could only refer to the lower reaches of the Bubastite or Pelusiac branch of the Nile. But since some quite explicit passages showed that Pi-Ralmesse lay near the sea, the obvious conclusion seemed to be that it was situated either at or near Pelusium, where the said river-arm debouched. The Egyptian evidence in connection with Pelusium was next discussed, and it was shown that tradition associated Avaris with that town. On the other hand, it appeared likely that the god Seth of Avaris and the god Seth of Pi$\mathrm{Ra}$ messe were identical, so that here again would be evidence in favour of the location of Pi-Ralmesse at Pelusium. Further consideration of the deities of Pi-Ralmesse led to the same result; and in particular the mention, on a monument from Bubastus, of "the temple of Prēe of Ramesses of The-Waters-of-the-Sun" recalled the fact that several slightly doubtful passages connected Pi-Ralmesse with "The-Waters-of-the-Sun"; the latter term was found to be a name of the Pelusiac Nile-arm, and this, once more, pointed to the identity of Pi-Ralmesse with Pelusium. Finally, the choice of Pelusium for the Delta Residence was seen to have been politically opportune, its situation being such that the Ramesside Pharaohs could thence control their ever increasingly restive tributaries in Palestine and Syria.

From the Egyptian city of Residence we passed on to the consideration of the Biblical Raamses-Rameses. It was first pointed out that either the Raamses of Exodus was Pi$\mathrm{Ra}^{\mathrm{C}}$ messe of the Pharaohs, or else it was another city of which the very existence had to be postulated. A consideration of the Old Testament passages and of their traditional interpretation showed that there was no real evidence that a town of Ramesses ever existed in or near the Wâdy Tûûilât; and it was further shown that, whether the Bible narrative be regarded as sound historical evidence or whether it be looked upon as purely legendary, in either case the scene of Moses' birth and struggles with the Pharaoh of the Oppression could only be located at the Delta Residence of the Ramesside Pharaohs, i.e. at Pi-RaCmesse at or near Pelusium. This conclusion proved quite reconcilable with the Biblical passages naming Raamses-Rameses. Lastly, examination showed that Professor Petrie's claim to have discovered Raamses at Tell er-Retâbeh lacked justification.

\section{Additions and Corrections.}

It was unfortunately necessary to print a small portion of this essay before the whole investigation was completed, so that a few minor inconsistencies have found their way into the text.

It ought to have been stated, at the outset, that the name of Ramsès formerly given to the railway-station at Maskhûtẹeh owed its existence to Lepsius' erroneous conclusions concerning the topography of the Wâdy Țûmîlât and its neighbourhood. Similarly, a doubtful inference on the part of the topographers of the Description de l'Égypte forms the basis of the name borne by the modern railway-station of Serapeum.

On p. 128, the statements with regard to Pithom and Succoth should be modified in accordance with the conclusions reached in the note on pp. 267-9. 
P. 129. A reference in AmÉLINeAu, La Géographie de l'Egypte à l'époque Copte, p. 402, was overlooked. In the first of the stories preserved in the Arabic book called "Forty edifying stories" (Ms. Bibl. Nat., no. 155, fol. 50), one monk says to another: "O my father, I am of a village of the land of Alexandria, which is called Ramsîs."

P. 131. The name of the temple mentioned on the Carnarvon scarab is probably to be translated "The-Castle-of-Ramesses-Beloved-of-Amün-Beloved-like-Tūm on the west of the (waters called) 'Ity." See p. 258, footnote 4.

P. 133. A kneeling statue of the "Royal Son of Kush, Pesiûr," a contemporary of Ramesses II, has an invocation to 4 mm 1 \% $\odot$ ( the-House-of-Ramesses-Beloved-of-Amün"; the owner's title renders it likely that $\mathrm{Abu}$ Simbel is here meant, rather than the Delta Residence. The statue is preserved in the British Museum (Exhib. no., 604; Invent. no., 1376); it is figured Arundale-Bonomi, Gallery of Antiquities, Pl. 51, and again in the official Guide to the Egyptian Galleries (1909), p. 197.

The sketch-map of the Eastern Delta accompanying this article (Plate XXXV) has been very carefully drawn by Messrs Emery Walker's skilled map-maker Mr Staton from the latest maps of the Egyptian Survey. 